ARCHIWA - KanCELARIE - ZBIORY

NR $4(6) / 2013$

PAULINA ŁaWNiCZAK

University of Nottingham

\title{
Sekretariat Stanu KsięStwa Warszawskiego (1807-1813)
}

Słowa kluczowe: Księstwo Warszawskie, Sekretariat Stanu Księstwa Warszawskiego, kancelaria akt czynności, Fryderyk August

Ke y w ord s: Duchy of Warsaw, Secretariat of State of the Duchy of Warsaw

Abstract

Urząd ministra sekretarza stanu Księstwa Warszawskiego powstał na mocy konstytucji z lipca 1807 roku. Sekretariat Stanu Księstwa Warszawskiego stanowił aparat pomocniczy ministra sekretarza stanu, a jego główną siedzibą, wynikającą z obowiązków urzędnika, było Drezno. Zatem cezura czasowa funkcjonowania Sekretariatu Stanu to lata 1807-1813. Głównym wyznacznikiem zadań, wykonywanych w Sekretariacie Stanu, były zadania, wynikające z obowiązków ministra sekretarza stanu. Tym obowiązkom podporządkowano system pracy kancelarii. Jakość wykonywanych zadań przy ich nadmiarze pozostawiała czasem wiele do życzenia. Jakkolwiek, Sekretariat Stanu stanowił jedyną drogę dla obywateli do skontaktowania się z monarchą. Gabinet Stanisława Augusta miał wspólne elementy z gabinetem saskim, a Sekretariat Stanu był kancelarią przy saskim królu. Zatem w przypadku tej kancelarii królewskiej możemy spodziewać się raczej kontynuacji wcześniejszych zwyczajów niż wprowadzenia nowej formy akt spraw, charakterystycznej dla XIX wieku. Argumentem przemawiającym za zastosowaniem w Sekretariacie Stanu znanych już rozwiązań, jest także fakt, że król saski był niechętny gwałtownym zmianom. Choć w Księstwie Warszaw- 
skim wprowadzano nowoczesne rozwiązania ustrojowe i kancelaryjne, to jednak Królestwo Saksonii było w tym okresie bardziej zachowawcze. Fryderyk August ostrożnie podchodził do przeprowadzanych w Księstwie reform i nie zamierzał w krótkim czasie przenosić ich na grunt saski. Mogło to także powodować sceptyczne podejście do nowoczesnej kancelarii akt spraw. Sekretariat Stanu został urządzony ogólnie według rozwiązań XVIII-wiecznych, z uwzględnieniem potrzeb kancelarii do spraw Księstwa Warszawskiego. Unowocześnienie polskiej kancelarii królewskiej, za jaką należy uznać Sekretariat Stanu Księstwa Warszawskiego, w tym przypadku stanowiły rozbudowane pomoce ewidencyjne. W kancelarii stanisławowskiej dopiero zaczynano wprowadzać dzienniki korespondencyjne ogólne. Akt królewski we wszystkich egzemplarzach: oryginał w archiwum, wpis w protokole sekretariatu stanu i kopia urzędowa, czyli wypis z protokołu sekretariatu stanu, powinien zawsze być zgodny co do treści. Według prawa odpowiadał za to minister sekretarz stanu. Niestety, przeglądając protokoły posiedzeń Rady Stanu, dowiadujemy się o uchybieniach w tym zakresie.

Aby móc uprawiać „naukę o akcie”, należy na pierwszym etapie badań poznać ustrój i uwarunkowania polityczne państwa, w którym ten akt powstał ${ }^{1}$. W 1807 roku na ziemiach polskich wprowadzone zostały francuskie modele kancelaryjne (np. układ chronologiczny akt), administracyjne (np. podział administracyjny) i prawne (np. konstytucja księstwa) ${ }^{2}$. Stanowisko państwowe Secretaire d'Etat ukształtowało się we Francji w XVI wieku³. W XVIII wieku sekretarz stanu nadzorował kancelarię królewską, kontrasygnował dekrety i edykty królewskie ${ }^{4}$. Jednakże w tym okresie w Saksonii również spotykamy się już ze stanowiskiem „ministra stanu” albo „sekretarza stanu”, a jego obowiązki są porównywalne z obowiązkami francuskiego odpowied-

1 T. Grygier, H. O. Meisner, Urkunden Und Aktenlehre der Neuzeit, Leipzig 1952, „Archeion”, t. 25, 1956, s. 386.

2 W. Rostocki, $Z$ badań porównawczych nad ustrojem administracyjnym Księstwa Warszawskiego i Francji, „Czasopismo Prawno-Historyczne”, t. XIII, 1961, s. 120-124. Przykładem zastosowania modelu francuskiego jest Ministerstwo Wojny. Tamże.

3 Sekretarz stanu, [w:] Wielka Encyklopedia PWN, t. 24, Warszawa 2004, s. 496. Sekretariat Stanu. [on-line] Dostęp na World Wide Web (2 IV 2009 r.): http:// www.vatican.va/roman_curia/secretariat_state/documents/rc_seg-st_12101998_ profile_pl.htm.

${ }^{4}$ Secretaire d'Etat. [on-line] Dostęp na World Wide Web (2 IV 2009 r.): http://fr.wikipedia.org/wiki/Secr\%C3\%A9taire_d\%27\%C3\%89tat_(Ancien_R\%C3\% A9gime)\#Historique. 
nika ${ }^{5}$. Według Rostockiego, w kancelariach Księstwa Warszawskiego spotykamy mniejsze lub większe wpływy stanisławowskie ${ }^{6}$. Kancelarie organów administracji terytorialnej stosują wybrane pomoce kancelaryjne $\mathrm{z}$ okresu stanisławowskiego (np. dziennik główny). Pomimo wyżej wspomnianej różnorodności wpływów z czasem w większości kancelarii Księstwa wprowadzony zostaje pruski rzeczowy układ $\mathrm{akt}^{7}$. Zatem jak przedstawiała się sytuacja Sekretariatu Stanu Księstwa Warszawskiego?

Urząd ministra sekretarza stanu Księstwa Warszawskiego powstał na mocy konstytucji z lipca 1807 roku. W październiku 1807 roku sześciu ministrów Księstwa Warszawskiego, w tym także minister sekretarz stanu, Stanisław Breza, złożyło przysięgę wierności Fryderykowi Augustowi. Sekretariat Stanu Księstwa Warszawskiego stanowił aparat pomocniczy ministra sekretarza stanu, a jego główną siedzibą, wynikającą z obowiązków urzędnika, było Drezno. Pierwszy dekret królewski wydany został pod datą 29 października 1807 roku $^{8}$. Dnia 26 grudnia 1807 roku Fryderyk August wystawił pierwszy dekret, dotyczący ministra sekretarza stanu i jego kancelarii ${ }^{9}$. Ze względu na zagrożenie wojną, w maju 1812 roku książę warszawski przekazał swoje uprawnienia Radzie Ministrów, która mogła teraz wydawać dekrety w imieniu władcy. Decyzja ta miała wpłynąć także na pracę Sekretariatu Stanu. Ostatni akt, według sumariusza dekretów królewskich, wydany został przez Fryderyka Augusta dnia 20 sierpnia 1813 roku $^{10}$. Zatem cezura czasowa funkcjonowania Sekretariatu Stanu, uznana także przez Kazimierza Konarskiego $^{11}$, to lata $1807-1813$.

5 W. Hahlweg, Die Grundzuge der Verfassung des Sächsischen Geheimen Kabinetts 1763-1831, "Zeitschrift für die Gesamte Staatswissenschaft”, Bd. 103, 1943, s. 35 .

6 W. Rostocki, Kancelaria i dokumentacja aktowa urzędów administracji w Księstwie Warszawskim i Królestwie Polskim (do 1867 r.), Warszawa 1964, s. 103.

7 Tenże, Kancelaria i dokumentacja aktowa urzędów administracji w Księstwie Warszawskim i Królestwie Polskim (do 1867 r.), Warszawa 1964, s. 104. Charakterystyka akt spraw: tamże, s. 62-66.

${ }^{8}$ Archiwum Główne Akt Dawnych (dalej cyt.: AGAD), Sekretariat Stanu Księstwa Warszawskiego (dalej cyt.: SSKW), sygn. 15.

9 Tamże, sygn. 15, s. 60.

10 Tamże, sygn. 9.

${ }^{11}$ K. Konarski, Archiwum Akt Dawnych w Warszawie, [w:] Straty archiwów i bibliotek warszawskich w zakresie rękopiśmiennych źródeł, t. 2, Warszawa 1956, s. 121. 
Pierwsze źródło, dotyczące zadań ministra sekretarza stanu, to dość ogólny projekt ministra sprawiedliwości Feliksa Łubieńskiego z 1807 roku $^{12}$, o który został poproszony podczas posiedzenia Rady Stanu ${ }^{13}$. Feliks Łubieński, układając zadania ministra sekretarza stanu, dążył do tego, aby oryginały wszystkich praw, stanowionych przez króla i rząd, znajdowały się w stolicy Polaków - Warszawie. Można uznać, że chciał w ten sposób ożywić wśród rodaków poczucie ponownego posiadania własnego państwa. W swoim pamiętniku Łubieński opisuje spotkanie z cesarzem Francuzów z końca 1806 roku. Napoleon unikał wówczas użycia słów „Polska” i „Polacy”, zwracając się do deputowanych per Warszawiacy ${ }^{14}$. Powstało Księstwo Warszawskie, nie Polskie. Władcą został monarcha saski. Pomimo dobrych stosunków polsko-saskich, rozwijających się przez kolejne unie personalne, władcą nie był Polak, a główną siedzibą monarchy było Drezno, nie Warszawa. W tych okolicznościach łatwiej zrozumieć motywację ministra sprawiedliwości, dążącego do utworzenia kompletnego zbioru i przechowywania oryginałów dokumentów królewskich na ziemiach polskich.

Po upływie tygodnia od pierwszego czytania tegoż projektu, powrócono do tematu podczas 35 sesji Rady Stanu. Tym razem każdy minister czytał projekt opisu swojej władzy i obowiązków, a minister sprawiedliwości czytał, oprócz własnego, dodatkowo projekt dotyczący ministra - naczelnika kancelarii królewskiej ${ }^{15}$. Na posiedzeniu Rady Stanu 4 marca 1808 roku, podczas dyskusji nad projektem, zdecydowano, że również sposób ekspedycji wyroków królewskich miał odbywać się podtug zwyczaju francuskiego ${ }^{16}$. Zgodnie z tym postanowieniem art. 75 stanowił:

Prawa przez Nas [króla - PŁ] sankcjonowane, ministrowi sprawiedliwości do Dziennika Praw, a ustawy, dekreta, reskrypta i rozkazy nasze bądź do Rady Stanu, bądź do którego z ministrów minister sekretarz stanu, gdzie należy, przesyta

${ }^{12}$ AGAD, Rada Stanu i Rada Ministrów Księstwa Warszawskiego (dalej cyt.: RS i RMKW), seria II, sygn. 4, s. 33-34.

13 Protokoty Rady Stanu Księstwa Warszawskiego, t. 1, oprac.. B. Pawłowski, cz. 1, Toruń 1960, s. 76.

${ }_{14}$ Pamiętniki Feliksa hr. Eubieńskiego ministra sprawiedliwości, oprac. W. Chomentowski, Warszawa 1890, s. 175-176.

15 Protokoty Rady Stanu Księstwa Warszawskiego, s. 94.

16 Tamże, s. 181. 
z ostrzeżeniem, które z nich $w$ Dzienniku Praw z woli naszej maja być publikowane ${ }^{17}$.

Zatem odrzucono proponowane dublowanie ekspedycji dekretów z Sekretariatu Stanu do ministra sprawiedliwości i Rady Stanu. Kolejny artykuł (76) odrzucił propozycję Łubieńskiego, dotyczącą składania oryginałów dokumentów, stanowiących prawa w warszawskim archiwum, nadzorowanym przez ministra sprawiedliwości. Wszystkie oryginały wystawianych dekretów miały być przechowywane w archiwum królewskim w Dreźnie pod opieką pracowników Sekretariatu Stanu.

Ostatecznie po kilku miesiącach dyskusji nad urządzeniem ministerstw, projekt przedstawiono królowi Dnia 20 kwietnia 1808 roku Fryderyk August wydał dekret, urządzający organy centralne, w tym także zadania ministra sekretarza stanu ${ }^{18}$.

Pierwsze wzmiankowane w dekrecie zadanie ministra sekretarza stanu to podpisywanie dokumentów królewskich (art. 69). W polskim prawodawstwie zasadę nieodpowiedzialności króla poprzez obowiązek kontrasygnaty przez ministra, członka Straży Praw, wprowadziła Konstytucja 3 maja ${ }^{19}$. Jak czytamy w ustawie sejmowej, dotyczącej Straży Praw, żadna decyzja królewska, podjęta podczas jej obrad, nie mogła wejść w życie bez podpisu ministra ${ }^{20}$. Kontrasygnata ministra została podtrzymana w okresie Księstwa Warszawskiego z drobną modyfikacją, uwzględniającą fakt, iż król na stałe przebywał w Dreźnie, a ministrowie, z wyjątkiem jednego, w Warszawie. Artykuł 3 omawianego dekretu stanowi, że każda ustawa, czyli tylko „prawa i urządzenia administracji publicznej”21, wymagają podpisu ministra wydziałowego. Marian Kallas stwierdza, że był to martwy zapis prawa, niestosowany w praktyce, ponieważ brak jest podpisów na aktach zamieszczonych w Dzienniku

${ }_{17}$ Dekret księcia warszawskiego Fryderyka Augusta z 20 kwietnia 1808 r. o organizacji ministerstw (dalej: Dekret o organizacji ministerstw), [w:] Historia ustroju i prawa w Polsce 1772/1795-1918. Wybór źródet, oprac. M. Kallas i M. Krzymkowski, Warszawa 2006, s. 68-74.

${ }^{18}$ Dekret o organizacji ministerstw, s. 74.

${ }_{19}$ M. Kallas, Konstytucja Księstwa Warszawskiego. Jej powstanie, systematyka i gtówne instytucje w związku z normami szczegótowymi i praktyką, Toruń 1970, s. 86.

20 Volumina Legum: Prawa, konstytucje i przywileje Królestwa Polskiego, Wielkiego Księstwa Litewskiego i wszystkich prowincji należących, t. IX, Kraków 1889, s. 267.

${ }^{21}$ M. Kallas, dz. cyt., s. 78. 
Praw $^{22}$. Jednak Ryszard Szawłowski, w monografii dotyczącej organów kontroli państwowej, zamieszcza reprodukcję dekretu, ustanawiającego Główną Izbę Obrachunkową (GIO), opublikowanego w Dzienniku Praw, na którym znajduje się kontrasygnata ministra sprawiedliwości ${ }^{23}$. W tomie I Dziennika Praw znaleźć można inne przykłady podpisu ministra sprawiedliwości lub ministra spraw wewnętrznych pod publikowaną ustawą. Minister z wydziału, do którego należała realizacja postanowień ustawy, podpisując ją, odpowiadał przed królem za egzekucję. Innym przykładem, świadczącym o realizacji postanowień wzmiankowanego artykułu, jest podpis ministra sprawiedliwości Feliksa Łubieńskiego, widniejący oprócz podpisu króla i ministra sekretarza stanu, na oryginalnym akcie królewskim, wydanym podczas posiedzeń sejmu w Warszawie ${ }^{24}$.

Realizując postanowienia artykułu 69, Breza dodawał adnotację przez króla minister sekretarz stanu. Minister sekretarz stanu jednoosobowo odpowiadał przed królem i rządem za oryginalność i autentyczność podpisu królewskiego. Zdarzało się, że na oryginale dekretu nanoszone były poprawki ${ }^{25}$. Minister odpowiadał za to, aby ogłaszano wersję zgodną z życzeniem władcy w momencie nanoszenia podpisu monarchy. Konieczność poświadczania podpisu królewskiego wymagała od ministra sekretarza stanu stałego przebywania przy władcy.

Kolejne zadanie ministra sekretarza stanu związane było z opieką nad pieczęcią gabinetową Fryderyka Augusta oraz przykładanie jej na wszystkie dokumenty królewskie (art. 71). Niestety nie udało się dotrzeć do dokumentu, który szczegółowo opisywał pieczęcie Fryderyka Augusta księcia warszawskiego. Opis pieczęci urzędu zamieszczono we wspomnianym wyżej dekrecie o Głównej Izbie Obrachunkowej. Nie ma takiego opisu dla Sekretariatu Stanu, więc należy szukać pieczęci na zachowanych dokumentach.

Wszystkie pieczęcie państwowe okresu Księstwa Warszawskiego miały w polu herb Księstwa Warszawskiego: na tarczy dzielonej w słup, w polu prawym herb Saksonii (naprzemianlegle dziesięć czarnych i złotych pasów, na których w skos korona ruciana zielona) ${ }^{26}$; w polu lewym herb Polski; tarcza

22 Tamże, s. 87.

${ }^{23}$ R. Szawłowski, Najwyższe Państwowe Organy Kontroli w Polsce w XIX wieku, Warszawa 1999, s. 136.

${ }^{24}$ AGAD, Sejm Księstwa Warszawskiego i Królestwa Polskiego, sygn. 4, s. 41.

${ }_{25}$ AGAD, Sekretariat Stanu Księstwa Warszawskiego, sygn. 11, nr 597.

${ }^{26}$ Herb Saksonii był jednocześnie herbem Wettinów. 
z koroną. W Sekretariacie Stanu używano trzech typów pieczęci: wielkiej stanu, gabinetowej (o dwóch średnicach) i urzędowej ministra. Odróżnienie typu pieczęci umożliwia analiza legendy, kształtu pieczęci, wielkości oraz materiału wykorzystanego do jej odciśnięcia. Analizy pieczęci dokonano w innym artykule.

\section{Organizacja Sekretariatu Stanu}

W okresie panowania Stanisława Augusta naczelnikiem, szefem gabinetu, był mianowany dożywotnio dyrektor. Stanowił on łącznik pomiędzy królem a pracownikami kancelarii królewskiej ${ }^{27}$. Wśród pracowników, podobnie jak już w czasach saskich, byli konsyliarze, których określano mianem „tajny” lub „prywatny”, dodając im znaczenia. Pełnili oni funkcje doradcze, mogli bezpośrednio kontaktować się z władcą, bez udziału dyrektora. Zatrudnieni sekretarze opracowywali korespondencję pod dyktando króla, konsyliarza bądź dyrektora lub na podstawie sporządzonej przez nich minuty. Sekretarz z tytułem pierwszego sekretarza był zastępcą naczelnika kancelarii. Wśród personelu byli także kopiści, zwani kancelarzystami, oraz kurierzy ${ }^{28}$.

W saskim Domestique Departament personel kancelarii stanowiło dwóch lub trzech sekretarzy tajnych, trzech registratorów i czterech kancelistów ${ }^{29}$. Dodatkowo na zamku w Dreźnie funkcjonowało archiwum królewskie, które gromadziło akta z trzech saskich departamentów: Domestique, Etranger oraz Militar. Archiwum miało osobno wyznaczony personel, który stanowili: archiwista, registrator oraz czterech tajnych kancelistów z tytułem sekretarza ${ }^{30}$. Registrator dbał o registraturę, rozdzielał akta na sprawy, sporządzał ekstrakty $\mathrm{z}$ akt, prowadził repertorium oraz ogólne roczne wykazy akt, wypożyczanych $\mathrm{z}$ archiwum. Kancelista był pomocnikiem registratora, sporządzał wyciągi z akt oraz czystopisy ${ }^{31}$.

Przyjrzyjmy się teraz personelowi Sekretariatu Stanu. W dekrecie o organizacji ministerstw w art. 10 mowa o tym, że każdy z ministrów ma potrzebna

\footnotetext{
27 M. Rymszyna, Gabinet Stanistawa Augusta, Warszawa 1962, s. 54-55.

28 Tamże, s. 55-56.

29 W. Hahlweg, Die Grundzuge der Verfassung des Sächsischen Geheimen Kabinetts 1763-1831, „Zeitschrift für die Gesamte Staatswissenschaft”, B. 103, 1943, s. 6.

30 Tamże, s. 31.

31 Tamże, s. 29-30.
} 
kancelarię pod naczelnictwem sekretarza generalnego ${ }^{32}$. W artykule, w którym Rostocki porównywał ustrój administracyjny polski i francuski, autor stwierdza, że wprowadzenie jeszcze w czasach Komisji Rządzącej stanowiska sekretarza generalnego i związanego z tym podwójnego dozoru nad czynnościami w kancelarii, zostało przejęte z modelu francuskiego ${ }^{33}$. Nadzór zwierzchni obejmował nadzór ogólnie nad czynnościami kancelaryjnymi, z kolei nadzór bezpośredni obejmował zakresem bliższe doglądanie tych czynności ${ }^{34}$. W przypadku ministerstwa wojny czy spraw wewnętrznych jednym z pracowników kancelarii był sekretarz generalny ${ }^{35}$. W przypadku kancelarii królewskiej nie ma wzmianki o stanowisku sekretarza generalnego, jest jednak szef biura ${ }^{36}$, o czym niżej.

W kwestii podwójnego nadzoru w kancelarii królewskiej - nie był to tylko model francuski. Podobny model organizacyjny spotykamy w polskiej kancelarii królewskiej. Kanclerz/podkanclerzy sprawował nadzór ogólny, a regent kancelarii sprawował nadzór bezpośredni nad czynnościami kancelaryjnymi.

Przyjrzyjmy się teraz stanowiskom pracy w Sekretariacie Stanu:

a) Minister sekretarz stanu - naczelnik kancelarii ${ }^{37}$ sprawujący ogólny nadzór nad całą kancelarią;

b) Sekretarz kancelarii, Protokolista - prowadził Protokót Sekretariatu Stanu przy ministrze;

c) Sekretarze Ekspediujący, zwani konsyliarzami ${ }^{38}$, w tym:

- Sekretarz tajny, szef biura - kierował i nadzorował bezpośrednio pracowników biura oraz wykonywane przez nich czynności. Przygotowywał propozycje załatwienia sprawy;

- Sekretarze kancelarii (w liczbie 2)

- Służący kancelarii (w liczbie 1)

- Sekretarz tajny, Archiwista, Registrator, Ekspedytor i Kasjer - przygotowywał propozycje załatwienia sprawy; prowadził archiwum Sekretariatu Stanu, sporządzał wypisy z akt i pomoce archiwalne, od-

${ }^{32}$ Dekret o organizacji ministerstw, s. 68.

33 W. Rostocki, $Z$ badań porównawczych nad ustrojem administracyjnym Księstwa Warszawskiego i Francji, „Czasopismo Prawno-Historyczne”, t. XIII, 1961, s. 124.

${ }_{34}$ Tenże, Kancelaria i dokumentacja, s. 22-27.

35 Tenże, $Z$ badań porównawczych, s. 116.

${ }^{36}$ AGAD, SSKW, sygn. 17, s. 129.

37 Zadania omówiono w poprzednim rozdziale.

38 J. Willaume, dz. cyt., s. 80. 
powiadał za kasę kancelarii, prowadził rachunki. Wypłacał pensje pracownikom, co sytuowało go w strukturze po szefie biura;

- Kancelista przy Registratorze - pomocnik Archiwisty, Registratora

- Sekretarz tajny - przygotowywał propozycje załatwienia sprawy; w strukturze stał niżej od powyższych, jednak miał szerszy zakres obowiązków niż sekretarze kancelarii;

- Sekretarz ekspedycji francuskiej (tylko w latach 1808-1809) ${ }^{39}$. Powyższe stanowiska wskazują na kombinację zadań zarówno personelu Gabinetu Stanisława Augusta, jak i saskiego Tajnego Gabinetu.

\section{Pensje pracowników}

Nieodłącznym elementem, związanym ze stanowiskami pracy, który rzuca światło na znaczenie personelu kancelarii, jest wynagrodzenie. W grudniu 1807 roku Stanisław Breza zwrócił się z prośbą do Rady Stanu o ustalenie projektu etatu, czyli budżetu, dla swojego biura ${ }^{40}$. Dnia 26 grudnia 1807 roku wydany został pierwszy dekret, dotyczący Sekretariatu Stanu. Określono w nim roczną pensję ministra sekretarza stanu równą innym ministrom, tj. w wysokości 27 000, licząc od dnia 1 października 1807 roku. Kwota roczna, przyznana na pensje dla pozostałych pracowników kancelarii, została wyznaczona na 60000 zł. W tym samym dekrecie nakazano wypłatę tylko połowę kwartalnie należnej na pensje kwoty, czyli 7500, ponieważ skład osobowy kancelarii nie był wówczas kompletny ${ }^{41}$. W marcu 1808 roku na kolejnym posiedzeniu Rady Stanu ministrowie zostali poproszeni o ułożenie etatów swoich biur ${ }^{42}$. Etat omawianej kancelarii, jako ustalony wcześniej, nie był ponownie rozpatrywany.

Kiedy mowa o wynagrodzeniu, to pracowników Sekretariatu Stanu spośród innych urzędników państwowych Księstwa Warszawskiego wyróżnił dekret z 7 listopada 1808 roku $^{43}$. Zostali oni zrównani w zakresie wysokości diet, wypłacanych podczas podróży i wyjazdu z Drezna, z innymi pracownikami Kancelarii Gabinetowej Królestwa Saskiego:

\footnotetext{
39 AGAD, SSKW, sygn. 17, s. 128-130.

40 AGAD, RS i RM KW, seria II, sygn. 4, s. 32.

41 AGAD, SSKW, sygn. 15, s. 60.

42 Tamże, s. 181.

43 M. Krzymkowski, dz. cyt., s. 96.
} 
- Dla sekretarza expediuiącego, dokąd i Registrator należy, Talerów sześć, groszy srebrnych Szesnaście.

- Dla sekretarza kancellaryi czyli Kancellisty Talerów dwa, groszy srebrnych szesnaście ${ }^{44}$.

Zaznaczono także, że wspomniane diety będą wypłacane z funduszu przeznaczonego na etat biura. Dla porównania, kiedy w lutym 1813 roku członkowie Rady Stanu przebywali w Piotrkowie, przyznano im diety w wysokości 2 zł od każdego tysiąca rocznej pensji ${ }^{4}$, co dla sekretarza generalnego kancelarii stanowiło w przeliczeniu zaledwie 4 talary. Z kolei kancelista Sekretariatu Stanu otrzymywał wyższą dietę niż podprefekt w Księstwie Warszawskim ${ }^{46}$.

Zaledwie dwa dni po podpisaniu przez króla powyższego dekretu, czyli 9 listopada 1808 roku, Stanisław Breza skierował notę do Rady Stanu, informując o wydanym dekrecie. W tym samym liście zwrócił się z wnioskiem o przyznanie pensji dla nowego sekretarza ekspedycji francuskiej w wysokości 7000 zł oraz o wypłacenie bonifikacji straty na różnicy monety w Królestwie Saskim i Księstwie Warszawskim w wysokości 9\%. W roku 1808 bonifikacja została wypłacona ze środków zaoszczędzonych z przyznanego wcześniej etatu. Na posiedzeniu 20 stycznia 1809 roku przyjęto budżet Sekretariatu Stanu, zmniejszając o 1000 zł pensję sekretarza ekspedycji francuskiej, w stosunku do kwoty postulowanej przez Brezę, ale przyznając specjalny dodatek na diety ${ }^{47}$. Dnia 6 marca 1809 Fryderyk August podpisał etaty ministerstw, w tym etat Sekretariatu Stanu ${ }^{48}$.

Kolejny etat kancelarii, tym razem szczegółowy, bo z dokładnym rozpisaniem kwot, został podpisany przez króla 1 stycznia 1810 roku. Nadal uwzględniano bonifikację straty na wymianie pieniędzy, jednak w zestawieniu wypłacanych pensji nie znajdziemy już sekretarza ekspedycji francuskiej ${ }^{49}$. Wygląda na to, że taki pracownik potrzebny był tylko w roku 1809 , być może ze względu na częstszą korespondencję w tym języku. Ponadto ze

${ }^{44}$ AGAD, SSKW, sygn. 15, s. 415.

${ }^{45}$ AGAD, Rada Ministrów Księstwa Warszawskiego, sygn. 6, s. 47.

${ }^{46}$ M. Krzymkowski, dz. cyt., s. 93.

47 Protokoty Rady Stanu Księstwa Warszawskiego, t. 2, oprac. B. Pawłowski i T. Mencel, cz. 2, Toruń 1968, s. 30. Por.: AGAD, RS i RM KW, seria II, sygn. 60, s. 4. ${ }^{48}$ Protokoty Rady Stanu Księstwa Warszawskiego, Toruń 1968, s. 156. Oryginał etatu: AGAD, RS i RM KW, seria II, sygn. 384, s. 442. Tekst dekretu: AGAD, SSKW, sygn. 16, s. 666.

49 AGAD, SSKW, sygn. 17, s. 129-130. 
szczegółowego etatu dowiadujemy się, że podobnie jak w 1808, także tym razem nie wykorzystano wszystkich funduszy przeznaczonych na biuro i na pensje kancelarii ministra sekretarza stanu.

W czasach Komisji Rządzącej, jeśli miały miejsce oszczędności, wówczas mogły być one wykorzystane na wynagrodzenie zdolniejszych pracowników ${ }^{50}$. W czerwcu 1810 roku Rada Ministrów zwróciła się do króla z zapytaniem o możliwość dokonywania modyfikacji w etatach. Fryderyk August wydał dekret dnia 22 sierpnia 1810 roku, na mocy którego wszelkie ujęcie pensji pracownika miało trafić z powrotem do skarbu państwa, a ewentualne nagradzanie wyróżniających się urzędników państwowych odbywać się mogło tylko za zgodą króla ${ }^{51}$.

Tabela 1. Osobowy wykaz zarobków w 1810 roku

\begin{tabular}{|c|c|c|}
\hline Lp. & $\begin{array}{c}\text { Stanowisko } \\
\text { (w nawiasie liczba zatrudnionych) }\end{array}$ & $\begin{array}{l}\text { Pensja roczna na osobę } \\
\qquad(\mathbf{w} \mathbf{z l})\end{array}$ \\
\hline 1) & $\begin{array}{l}\text { Sekretarz tajny i gabinetowy, szef biura } \\
\text { Stanisław Michalski }\end{array}$ & 12000 \\
\hline 2) & $\begin{array}{l}\text { Sekretarz tajny, archiwista, registrator, ekspedytor, kasjer } \\
\text { Michał Hube }\end{array}$ & 8000 \\
\hline 3) & $\begin{array}{l}\text { Sekretarz tajny } \\
\text { Wawrzyniec Surowiecki }\end{array}$ & 7000 \\
\hline 4) & $\begin{array}{l}\text { Sekretarz kancelarii, protokolista } \\
\text { Maciej Wierzejski }\end{array}$ & 5000 \\
\hline 5) & $\begin{array}{l}\text { Sekretarz kancelarii (3) } \\
\text { Jan Antoni Hinkelman, Jan Młodzianowski, Jan Wernicke }\end{array}$ & 4333 zł $10 \mathrm{gr}$ \\
\hline 6) & Kancelista przy registraturze (vacat) & 3000 \\
\hline 7) & $\begin{array}{l}\text { Służący kancelarii } \\
\text { Fryderyk Myczka }\end{array}$ & 2000 \\
\hline & Razem & 50000 \\
\hline
\end{tabular}

Źródło: AGAD, Sekretariat Stanu Księstwa Warszawskiego, sygn. 17, s. 129-130.

Sytuacja finansowa Księstwa Warszawskiego stale pogarszała się. W pierwszych miesiącach nowego roku król wydał dwa dekrety $(20$ stycz-

50 AGAD, Komisja Rządząca, seria II, sygn. 30, s. 117.

51 AGAD, SSKW, sygn. 17, s. 643. 
nia i 17 kwietnia 1812 r. $)^{52}$, w których nawoływał do sporządzenia projektów etatów w duchu oszczędności, obiecanych podczas posiedzenia sejmu pod koniec 1811 roku. Dekretem z dnia 11 grudnia $1811^{53}$ roku król zawieszał pensje pracowników administracji państwowej z wyłączeniem pracowników Sekretariatu Stanu. Po raz kolejny mamy do czynienia z wyróżnieniem pracowników kancelarii królewskiej. W listopadzie 1812 roku Rada Ministrów, powołując się na nadane sobie uprawnienia od króla, wydała dekret, stanowiący, iż ${ }^{1 / 4}$ pensji należnej pracownikom administracji pozostanie w skarbie ${ }^{54}$. Dekretem królewskim z 13 stycznia 1813 roku pracownicy Sekretariatu Stanu zostali wyłączeni spod mocy prawnej dekretu Rady Ministrów, nakazującego oszczędności ${ }^{55}$. Co więcej, na mocy kolejnego aktu królewskiego, z dnia 1 lutego 1813 roku, przyznane zostały dodatkowe pensje dla niektórych oficjalistów kancelarii królewskiej ${ }^{56}$.

Tabela 2. Osobowy wykaz zmian pensji w 1813 roku

\begin{tabular}{|c|c|c|}
\hline Lp. & $\begin{array}{c}\text { Stanowisko } \\
\text { (w nawiasie liczba zatrudnionych) }\end{array}$ & $\begin{array}{l}\text { Pensja roczna na osobę } \\
\text { (w zl) }\end{array}$ \\
\hline 1) & $\begin{array}{l}\text { Sekretarz tajny i gabinetowy, szef biura } \\
\text { Stanisław Michalski }\end{array}$ & 12000 \\
\hline 2) & $\begin{array}{l}\text { Sekretarz tajny, archiwista, registrator, ekspedytor, } \\
\text { Jan Młodzianowski }\end{array}$ & 8000 \\
\hline 3) & $\begin{array}{l}\text { Sekretarz tajny } \\
\text { Maciej Wierzejski }\end{array}$ & 7000 \\
\hline 4) & $\begin{array}{l}\text { Sekretarz kancelarii, protokolista } \\
\text { Jan Antoni Hinkelman }\end{array}$ & 5000 \\
\hline 5) & $\begin{array}{l}\text { Sekretarz kancelarii (2) + sekretarz kancelarii kasjer (1) } \\
\text { Jan Wernicke, Antoni Poszmański + Michał Hube }\end{array}$ & 4333 zł $10 \mathrm{gr}$ \\
\hline 6) & Kancelista przy registraturze (nieznany) & 3000 \\
\hline 7) & $\begin{array}{l}\text { Służący kancelarii } \\
\text { Fryderyk Myczka }\end{array}$ & 2000 \\
\hline & Razem & 50000 \\
\hline
\end{tabular}

Źródło: AGAD, SSKW, sygn. 17, s. 129-130. BJ, rkps. 5021.

52 AGAD, SSKW, sygn. 20, s. 48-49, 444-445.

53 M. Krzymkowski, dz. cyt., s. 79.

54 Tamże, s. 82.

55 AGAD, SSKW, sygn. 9, k. 97.

56 Tamże, k. 99. 
Pracownicy kancelarii przy królu jeszcze w styczniu 1814 roku otrzymali swoje pensje. Rozpatrując przywileje królewskie, Sekretariat Stanu był najlepszym miejscem zatrudnienia pod względem finansowym dla urzędnika państwowego Księstwa. Jednakże takie wyróżnienie przez króla saskiego staje się bardziej zrozumiałe, gdy spojrzymy na niektóre łaski królewskie, przyznawane ministrom gabinetowym saskiego Gabinetu Tajnego: zwolnienie z podatków, akcyzy i podatku od wina, wydawanie darmowych leków w głównej aptece $^{57}$. Warto wspomnieć w tym miejscu, że zwiększona troska o pracowników kancelarii królewskiej nie była obca władcom polskim. Podobną sytuację obserwujemy za panowania Stanisława Augusta, który okazywał troskę w zakresie zdrowia i warunków bytowych pracowników swojego gabinetu ${ }^{58}$.

\section{FUNKCJONOWANIE KANCELARII}

Koszty utrzymania kancelarii w Dreźnie. Powołując się na dekret królewski, minister skarbu Tadeusz Dembowski w liście z dnia 30 grudnia 1807 roku informuje Radę Stanu, że na wydatki biura rocznie przeznaczono 16000 zł $^{59}$. Niestety nie znamy szczegółowo wydatków za ten rok. Z memoriału rezydenta francuskiego Serry z czerwca 1808 roku dowiadujemy się, że minister skarbu wypłacił do tego czasu na potrzeby Sekretariatu w Dreźnie $100000 \mathrm{zf}^{60}$, co stanowi potwierdzenie wypłaty zgodnie z ustalonym pod koniec 1807 roku etatem.

Przewidując koszty utrzymania dla kancelarii, przeoczono fakt, że przebywając stale przy królu, będzie ona miała swoją siedzibę głównie w Dreźnie, a nie w Warszawie. Pominięto także ważną cechę Sekretariatu Stanu, a mianowicie taką, że będzie podróżował z królem, z czego wynika konieczność pokrycia kosztów podróży. W listopadzie 1808 roku Breza zwrócił się z prośbą do Rady Stanu o dokonanie korekty etatu i uwzględnienie kosztów podróży oraz bonifikacji straty, wynikającej z wymiany pieniędzy ${ }^{61}$. Budżet Księstwa Warszawskiego ustalany był w złotych polskich, z kolei w Saksonii środkiem płat-

57 W. Hahlweg, Die Grundzuge der Verfassung des Sächsischen Geheimen Kabinetts 1763-1831, Zeitschrift für die Gesamte Staatswissenschaft, Band 103, 1943, s. 26.

58 M. Rymszyna, dz. cyt., s. 62-63.

59 AGAD, Rada Ministrów Księstwa Warszawskiego, seria II, sygn. 53, k. 1.

${ }^{60}$ Instrukcje i depesze rezydentów francuskich, s. 670.

${ }^{61}$ AGAD, RS i RM KW, seria II, sygn. 60, s. 1. 
niczym były talary. Różnica wartości obu walut wynosiła początkowo 9\%. Po przeliczeniu stanowiło to konieczność dopłaty w wysokości 1440 zł polskich do kwoty pierwszego etatu biura w skali roku. W 1808 roku te dodatkowe koszty udało się pokryć z zaoszczędzonych środków, przyznanych na utrzymanie biura ${ }^{62}$. W budżecie na 1809 rok dodano 5000 zł na koszty podróży z Najjaśniejszym Panem oraz bonifikację straty na zamianie pieniędzy ${ }^{63}$. Zatem od 1809 roku na wydatki kancelarii ze skarbu Księstwa Warszawskiego wypłacano 21000 zł z dopłatą 1890 zł, czyli łącznie 22890 zł polskich.

W roku 1810 nie zmieniono przyznanej kwoty. Z protokołu Sekretariatu Stanu dowiadujemy się, na co ogólnie przeznaczano środki finansowe, wypłacone ze skarbu państwa. W zamieszczonej poniżej tabeli w wydatkach kancelarii uwzględnione zostały m.in. opłaty pocztowe i ekspedycja. W styczniu 1808 roku, w odezwie do Rady Stanu, Breza informuje, że na ekspedycjach rządowych, które mają być zwolnione z opłat pocztowych, według rozkazu królewskiego należy zamieścić wyraźną adnotację na kopercie ex officio ${ }^{64}$. W dekrecie, dotyczącym Głównej Izby Obrachunkowej, w artykule 11 potwierdzono ten przywilej ${ }^{65}$. Kancelaria królewska, jeżeli okazjonalnie korzystała z tego dobrowolnego przywileju, to raczej go nie nadużywała, ponieważ brak adnotacji na zachowanych kopertach ${ }^{66}$.

W tym okresie kancelaria Rady Stanu sporządziła bardzo szczegółowy wykaz swoich wydatków. Dowiadujemy się z niego, że sztych ${ }^{67}$ tytułów na dekreta królewskie kosztował 112 zł, a mała pieczęć do ekspedycji 24 zł ${ }^{68}$. Z kolei światło, czyli świece, to - w zależności od rodzaju - wydatek rzędu 1 zł za funt świec „rurkowych”, a 26 groszy za „ciągnionych” ${ }^{6}$. Papier wykorzystywany w kancelarii pochodził częściowo z fabryk saskich, a częściowo z nadwornej fabryki papieru w Jeziornie, która dekretem z dnia 9 maja 1812 roku zyskała przywilej i tytuł królewskiej fabryki papieru ${ }^{70}$.

${ }_{62}$ Tamże, s. 1.

${ }^{63}$ Tamże, sygn. 384, s. 442.

${ }^{64}$ Tamże, sygn. 350, s. 19.

${ }^{65}$ R. Szawłowski, dz. cyt., s. 281.

${ }^{66}$ AGAD, RS i RM KW, seria II, sygn. 350, s. 127.

${ }^{67}$ Sztych - rycina wykonana w metalowej płycie; posmarowany farbą służył do odbijania rysunków na papierze.

${ }^{68}$ AGAD, RS i RM KW, seria II, sygn. 3, s. 173.

${ }_{69}$ M. Krzymkowski, Status prawny urzędników Księstwa Warszawskiego, Poznań 2004, s. 88.

70 AGAD, SSKW, sygn. 20, s. 576-577. 
Tabela 3. Etat szczegółowy wydatków biura w 1810 roku

\begin{tabular}{|c|l|c|}
\hline Lp. & \multicolumn{1}{|c|}{ Koszty utrzymania biura } & $\begin{array}{c}\text { Kwota w zł pl } \\
\text { + bonifikacja straty }\end{array}$ \\
\hline 1$)$ & $\begin{array}{l}\text { Materiały piśmienne, potrzeby ekspedycji, druki, poczta, } \\
\text { gazety, światło, pieczęcie i inne utensylia kancelarii i ich re- } \\
\text { paracja }\end{array}$ & $\begin{array}{l}11400 \\
+1026\end{array}$ \\
\hline 2$)$ & $\begin{array}{l}\text { Koszta w drodze rachując podróż do Warszawy i na powrót, } \\
\text { upakowanie archiwum, trynkgielty ośmiu pocztylionom, } \\
\text { eskorcie przy powozach i inne koszta }\end{array}$ & 2800 \\
\hline 3$)$ & $\begin{array}{l}\text { Na nieprzewidziane wydatki, kupno książek i na zastąpienie } \\
\text { przypadkowe deficytu w artykułach na powyższe }\end{array}$ & 3800 \\
\hline & razem & +342 \\
\hline
\end{tabular}

Źródło: AGAD, SSKW, sygn. 17, s. 129.

Uruchomienie w Warszawie mennicy oraz wydanie dnia 18 grudnia 1810 roku dekretu o wprowadzeniu nowej edycji banknotów, miały wpływ na budżet urzędów. Od stycznia 1811 roku zmianie uległ przelicznik złotego i talara. Z wcześniejszej różnicy wynoszącej 9\%, teraz stosunek walut wynosił 6 zł za 1 talara $^{71}$. Na podstawie potwierdzenia otrzymania pensji w 1813 roku przez pracowników Sekretariatu Stanu, można wnioskować, że uregulowanie sytuacji walutowej przyczyniło się do zniesienia bonifikacji straty na zamianie pieniędzy ${ }^{72}$.

Niestety, powyżej cytowany dekret z 1810 był jedynym szczegółowym dekretem, dotyczącym kosztów utrzymania Sekretariatu Stanu. Uwzględniając fakt, iż koszty ponoszone z tytułu funkcjonowania administracji były raczej stałe, można uznać, że kwota 21000 zł była kwotą wypłacaną do końca działalności kancelarii. Dla porównania, na funkcjonowanie kancelarii Rady Stanu dekretem królewskim z dnia 4 marca 1812 roku wyznaczono $15000 \mathrm{zf}^{73}$. Jest to zatem zbliżona kwota utrzymania kancelarii urzędów centralnych.

${ }^{71}$ Dekret księcia warszawskiego Fryderyka Augusta odnośnie wprowadzenia na terenie Księstwa Warszawskiego nowej edycji banknotów z 18 XII 1810 roku. [on-line] Dostęp na World Wide Web (20 V 2009 r.): Skarby Dziedzictwa Narodowego, http://dziedzictwo.polska.pl/katalog/skarb, Rozporzadzenie_Fryderyka_Augusta_odnosnie_wprowadzenia_na_terenie_Ksiestwa_Warszawskiego_nowej_edycji_banknotow_z_18_XII_1810_roku, gid, 247858, cid, 4645.htm?body=desc.

72 Szczegółowe omówienie w rozdziale o personelu kancelarii.

73 AGAD, SSKW, sygn. 20, s. 271. 
Podczas kwerendy nie udało się dotrzeć do informacji o wydatkach Sekretariatu Stanu w latach 1811-1813, także z powodu licznych zniszczeń, którym uległy polskie archiwalia. Jednak nie jest to jedyny powód uniemożliwienia dalszych badań. Pod koniec 1808 roku na mocy dekretu królewskiego ustanowiono Główną Izbę Obrachunkową. W artykułach 44 i 45 stanowiono, że każdy minister do 1 września danego roku prześle rachunki, których poprawność sprawdzi $\mathrm{GIO}^{74}$. Kwity dostarczane do sprawdzenia miały być opatrzone podpisem przełożonych kasy i kasjera (art. 60) ${ }^{75}$. Również dekret o organizacji ministerstw $\mathrm{w}$ artykule 16 nakładał na ministrów obowiązek rozliczania rachunków ${ }^{76}$. Niestety, niewiele rachunków przesyłano do rozliczenia. Edward Bignon, wspominając rok 1811 w Księstwie Warszawskim, komentuje niekompetentne administrowanie ze strony ministerstwa skarbu. Dość dobitnie podsumował zaistniałą sytuację, mówiąc, że byta izba obrachunkowa, a rachunków nie byto; komisja likwidacyjna, a żaden dtug nie byt zlikwidowany ${ }^{7}$.

Również na działalność kancelarii królewskiej padł cień, gdyż należała ona do grona urzędów państwowych, które dopuściły się zaniedbania w rozliczaniu swoich rachunków. Dnia 30 listopada 1812 roku Główna Izba Obrachunkowa wysłała do Drezna list, w którym przypomina kancelarii o przesłaniu rachunków, dotyczących kasy Sekretariatu Stanu za kolejne lata od 1808 roku począwszy ${ }^{78}$. Minister sekretarz stanu, dowiedziawszy się o niewłaściwym wypełnianiu obowiązków przez kasjera, ukarał Hubego obniżając jego pensję z 8000 zł do 4333 zł rocznie ${ }^{79}$.

Omawiając koszty utrzymania biura, należy także wspomnieć o obowiązujących opłatach kancelaryjnych. W projekcie organizacji Sekretariatu Stanu Łubieński określił, że za przygotowanie nominacji, agratiandi (łaski okazanej skazanym na śmierć) lub innej łaski królewskiej poszczególne wydziały ministerstw powinny przesyłać do Drezna z tego tytułu opłaty, tzw. jurium cancellariae $^{80}$, czyli zwrot kosztów druku. W styczniu 1808 roku na posiedze-

${ }^{74}$ R. Szawłowski, dz. cyt., s. 288.

75 Tamże, s. 293.

${ }^{76}$ Dekret o organizacji ministerstw, s. 69.

77 Polska w 1811 i w 1813 roku, s. 64-65.

78 AGAD, SSKW, sygn. 29, k. 228.

79 Biblioteka Jagiellońska, rkps. 5021, k. 26.

${ }^{80}$ AGAD, RS i RM KW, seria II, sygn. 4, s. 33. 
niu Rady Stanu minister skarbu przedstawił taryfę opłaty papieru stemplowego na patenty, według ustawy ostatniego sejmu Rzeczypospolitej. Złożył także ordynację Jurium Cancellariae, przepisów kancelaryjnych, sporządzoną przez pieczętarzy w 1765 roku $^{81}$.

W marcu 1808 roku minister sekretarz stanu w odezwie do Rady Stanu informował o konieczności przygotowania projektu, który wyszczególni urzędy i funkcje oraz pobieraną od nich opłatę jurium cancellariae oprócz opłaty papieru stemplowego ${ }^{82}$. Decyzją królewską, urzędnicy po nominacji na stanowisko wnosili opłatę stemplową oraz dodatkową opłatę kancelaryjną za druk m.in. nominacji, instrukcji, roty przysięgi, w kwocie od kilku do ponad $20 \mathrm{zt}^{83}$.

W kolejnej odezwie do Rady Stanu, w listopadzie 1808 roku, Stanisław Breza, zwracając się z prośbą o zwiększenie etatu biura, podkreśla fakt, że opłata jurium cancellariae nie była dotychczas i nadal nie jest pobierana przez kancelarię królewską ${ }^{84}$. Marek Krzymkowski szeroko omawia zarówno problem wysokości opłat związanych z nominacjami urzędników, jak i niezadowolenie społeczne, które one wzbudziły ${ }^{85}$. W przypadku, kiedy Sekretariat Stanu zatwierdzał nominacje ministrów, a de facto w urzędach w Księstwie Warszawskim następowało zaprzysiężenie na stanowisko, słusznym było zrezygnowanie z podwójnego pobierania opłaty od obywateli wstępujących na urzędy.

Takie rozstrzygnięcie problemu opłaty za czynność kancelarii kreowało bardziej pozytywny obraz króla w oczach poddanych. Urzędnik niższego szczebla, wnosząc opłatę w związku z objęciem stanowiska, swoje niezadowolenie kierował przeważnie do osób, którym realnie tę opłatę uiszczał. Poddany księcia warszawskiego otrzymywał łaskę władcy i nie musiał z tego tytułu ponosić kosztów w kancelarii królewskiej. Opłaty wnoszono w urzędach krajowych i to one miały z tego tytułu negatywny obraz w społeczeństwie.

\footnotetext{
81 Protokoty Rady Stanu Księstwa Warszawskiego, Toruń 1960, s. 99.

${ }^{82}$ AGAD, RS i RM KW, seria II, sygn. 350, s. 40.

83 M. Krzymkowski, dz. cyt., s. 54.

${ }^{84}$ AGAD, RS i RM KW, seria II, sygn. 60, s. 2.

85 M. Krzymkowski, dz. cyt., s. 51-54.
} 


\section{O AKTACH W SZCZEGólNości}

Dziatalność urzędu znajduje odbicie i utrwalenie na piśmie w aktach, które wytwarza jego kancelaria ${ }^{86}$. Na działalność urzędu, na powstające w nim akta, wpływ miały podróże króla, a co za tym idzie - mobilność Sekretariatu Stanu. Mając ograniczone zaufanie do rządu warszawskiego oraz wykazując zainteresowanie nowym państwem, książę warszawski kilka tygodni w roku spędzał w Warszawie. Władca korzystał z pobytu w stolicy Księstwa, by bezpośrednio kontaktować się z ministrami. Zimą 1807 roku Fryderyk August współpracował z rządem w celu rozwiązania najpilniejszych problemów nowo powstałego państwa, w wyniku czego zaobserwować można intensywną produkcję aktową tego okresu. Z kolei zimą 1808 roku obradował pierwszy Sejm Księstwa Warszawskiego. Interesujące jest zjawisko, że pobyt w Warszawie, choć stanowił istotny czynnik wzrostu liczby wydawanych dekretów, to w skali roku nie stanowił wyróżnienia. Dokumenty Fryderyka Augusta wystawione w Warszawie procentowo w skali roku przedstawiają się następująco: w 1807 roku - 89\%, w 1808 roku $-28 \%$, w 1809 roku $-44 \%$.

W Pałacu w Pilnic książę przebywał w miesiącach letnich, ponieważ była to letnia rezydencja władców saskich. W okresie zagrożenia wojną król opuszczał Drezno, jak to było w 1809 roku. Kolejna prawidłowość to wystawianie dokumentów w pałacach królewskich, a nie w podróży. Z drugiej strony, gdyby książę wydał dekret na postoju podczas dłuższej podróży, to w jaki sposób uzupełnionoby datację na formularzu dekretu: $w$ Patacu $N a-$ szym...?

86 W. Rostocki, Kancelaria i dokumentacja, s. 61. 
Tabela 4. Miejsce wystawienia dekretów Fryderyka Augusta X 1807-X 1809

\begin{tabular}{|c|c|c|c|c|c|c|c|c|}
\hline \multirow[b]{2}{*}{ Rok } & \multirow[b]{2}{*}{ Miesiąc } & \multirow[b]{2}{*}{ 1. d. } & \multicolumn{6}{|c|}{ Liczba dekretów wystawionych w danym miejscu } \\
\hline & & & Drezno & Warszawa & Pilnic & Lipsk & $\begin{array}{l}\text { Frankfurt } \\
\text { n. Menem }\end{array}$ & Erfurt \\
\hline \multirow[t]{4}{*}{1807} & Październik & 4 & 4 & & & & & \\
\hline & Listopad & 5 & 3 & 2 & & & & \\
\hline & Grudzień & 76 & & 76 & & & & \\
\hline & razem: & 85 & 7 & 78 & & & & \\
\hline \multirow[t]{13}{*}{1808} & Styczeń & 23 & 23 & & & & & \\
\hline & Luty & 18 & 18 & & & & & \\
\hline & Marzec & 60 & 60 & & & & & \\
\hline & Kwiecień & 39 & 39 & & & & & \\
\hline & Maj & 45 & 1 & & 44 & & & \\
\hline & Czerwiec & 60 & 9 & & 51 & & & \\
\hline & Lipiec & 53 & 8 & & 45 & & & \\
\hline & Sierpień & 33 & 5 & & 28 & & & \\
\hline & Wrzesień & 64 & 9 & & 55 & & & \\
\hline & Październik & 8 & 6 & & & & & 2 \\
\hline & Listopad & 70 & & 70 & & & & \\
\hline & grudzień & 86 & & 86 & & & & \\
\hline & Razem: & 559 & 178 & 156 & 223 & & & 2 \\
\hline \multirow[t]{12}{*}{1809} & Styczeń & 65 & & 65 & & & & \\
\hline & Luty & 57 & & 57 & & & & \\
\hline & Marzec & 105 & & 105 & & & & \\
\hline & Kwiecień & 42 & 19 & & & 23 & & \\
\hline & Maj & 19 & & & & 19 & & \\
\hline & Czerwiec & 32 & & & & 10 & 22 & \\
\hline & Lipiec & 23 & & & & & 23 & \\
\hline & Sierpień & 40 & 33 & 1 & & & 6 & \\
\hline & Wrzesień & 64 & 64 & & & & & \\
\hline & Październik & 62 & 62 & & & & & \\
\hline & Razem: & 511 & 180 & 228 & & 52 & 51 & \\
\hline & RAZEM: & 1155 & 365 & 462 & 223 & 52 & 51 & 2 \\
\hline
\end{tabular}

Źródło: opracowanie własne na podst. AGAD, SSKW, sygn. 15-16. 


\section{OBIEg PISM}

Nauka o aktach według Meissnera obejmuje zbadanie wszystkich etapów życia pisma: od kancelarii, poprzez registraturę, a na archiwum kończąc (tzw. genetyka). Nie bez znaczenia pozostaje także styl aktów (tzw. systematyka). Również ważna jest rola analityki aktów:

Cecha zewnętrzna aktu, jak wielkość, rozktad pisma, materiat piśmienniczy itp., następnie cechy wewnętrzne jak tytulacja, adres, promulgacja, narracja, dyspozycja, sankcja itp. sq ważnymi elementami wyrażania stosunku wystawcy do odbiorcy ${ }^{87}$.

Na podstawie samych akt, pomimo ich szczątkowego zachowania, możemy także poznać czynności kancelaryjne Sekretariatu Stanu. Obieg pisma to szereg czynności kancelaryjnych, w których wyniku powstaje dokumentacja załatwienia sprawy ${ }^{88}$. W omówionym schemacie uwzględniono także miejsce czynności merytorycznych, aby sam obieg stał się bardziej przejrzysty. W zależności od przedmiotu i znaczenia sprawy, pismo miało kolejne etapy życia. Poniżej przedstawiono także wynik analizy zachowanych akt Sekretariatu Stanu, Testamentu Politycznego Fryderyka Augusta oraz cytowanych wcześniej dekretów.

$\mathrm{Na}$ mocy dekretu z 1808 roku minister sekretarz stanu był jedyną osobą upoważnioną do odbierania korespondencji rządowej (art. 72). Wszelkie raporty lub odezwy od Rady Stanu lub ministrów królewskich powinien otworzyć i przedstawić królowi (art. 73). Wyjątek stanowiły pisma z adnotacją na kopercie do rąk wtasnych królewskich (art. 74).

Kiedy do Pałacu Królewskiego ${ }^{89}$ przybyła sztafeta pocztowa, minister sekretarz stanu odbierał listy. Następnie dokonywał rejestracji pism w Dzienniku Kancelarii JW. Ministra Sekretarza Stanu ${ }^{90}$, będącym również narzędziem kontrolnym pracy personelu. Rubryki dziennika zajmowały dwie strony (Rysunek 1).

87 T. Grygier, dz.c yt., s. 386.

88 W. Rostocki, Kancelaria i dokumentacja, s. 42.

89 Jednego z pałaców Fryderyka Augusta: Drezno, Warszawa, Pilnic (letnia rezydencja Wettinów).

90 AGAD, SSKW, sygn. 22. 
Rysunek 1. Dziennik Kancelarii JW. Ministra Sekretarza Stanu

\begin{tabular}{|l|c|c|c|c|}
\hline No & Datum Exhibiti & $\begin{array}{c}\text { Nazwisko } \\
\text { podającego }\end{array}$ & Treść podania & Referent \\
\hline
\end{tabular}

\begin{tabular}{|c|c|c|c|c|c|}
\hline $\begin{array}{c}\text { Datum } \\
\text { Rezolucji }\end{array}$ & $\begin{array}{c}\text { Treść } \\
\text { Rezolucji } \\
\text { czyli Dekretu }\end{array}$ & $\begin{array}{c}\text { Oddano } \\
\text { do Kancelarii } \\
\text { dnia, miesiąca }\end{array}$ & $\begin{array}{l}\text { Przepisano } \\
\text { przez }\end{array}$ & $\begin{array}{c}\text { Kiedy } \\
\text { odesłana } \\
\text { Rezolucja } \\
\text { i do kogo }\end{array}$ & $\begin{array}{c}\text { Akta } \\
\text { do których nota } \\
\text { i koncept } \\
\text { wzięty }\end{array}$ \\
\hline
\end{tabular}

Źródło: AGAD, SSKW, sygn. 22.

Dziennik prowadzono według kolejności wpływu, niezależnie od nadawcy czy przedmiotu sprawy. Nie był on prowadzony w systemie rocznym, a nadawanie sygnatury odbywało się w ramach tomu dziennika. Odwołanie do tego dziennika zapisywano na każdym oryginale dekretu królewskiego. Dziennik stanowił rejestr dokumentów podpisanych przez króla i tych opatrzonych pieczęcią gabinetową. Kiedy sporządzano kopię urzędową dekretu, w lewym dolnym rogu powtarzano numer z dziennika ministra sekretarza stanu.

Prowadzenie takiej pomocy ewidencyjnej może być kontynuacją działań z XVIII wieku. W 1716 roku August II podjął pierwszą próbę uporządkowania systemu sporządzania spisów dokumentów, które podpisywał i na których wyciskano pieczęć królewską.

(...) Dla uniknięcia zamieszania i zaskoczenia wszystkie przywileje i wszelkie inne papiery, w przysztości przedstawione królowi do podpisu (...) powinny być najpierw ztożone na ręce sekretarza królewskiego (...), przez samych zainteresowanych lub przez ich przedstawicieli. Zadaniem sekretarza byto zbadanie czy sq one utożone zgodnie z wymaganym stylem i forma i nie zawieraja uchybień jednego czy drugiego rodzaju. Następnie (...) miat zarejestrować wspomniane dokumenty w księdze specjalnie do tego celu przygotowanej (... $)^{91}$.

Po rejestracji minister dokonywał podziału korespondencji według nadawcy.

${ }^{91}$ H. Palkij, Kancelaria królewska w systemie politycznym Rzeczypospolitej. Problem analizy źródet masowych, [w:] Polska kancelaria królewska czasów nowożytnych między wtadza a spoteczeństwem, pod red. W. Chorążyczewskiego i W. Krawczuka, Toruń 2003, s. 76-77. 
Pisma urzędowe od Rady Stanu lub ministrów rejestrowano w Journalu Sekretariatu Stanu Przychodzacych i Odchodzacych Rzeczy oraz stawiano na piśmie prezentę (w Tabeli 5 podano przykładowe wpisy).

Tabela 6. Journal Sekretariatu Stanu przychodzących i odchodzących rzeczy

\begin{tabular}{|c|c|l|c|}
\hline $\begin{array}{c}\text { Numer } \\
\text { dziennika }\end{array}$ & $\begin{array}{c}\text { Data } \\
\text { podania }\end{array}$ & \multicolumn{1}{|c|}{$\begin{array}{c}\text { Poczta z dnia... } \\
\text { Treść Podania }\end{array}$} & $\begin{array}{c}\text { Decyzja } \\
\text { Najjaśniejszego Pana }\end{array}$ \\
\hline 2441 & 31 VIII 1812 & $\begin{array}{l}\text { Minister Sprawiedliwości } \\
\text { Przesyta M[ministrowi] S[ekretarzowi] } \\
\text { S[tanu] zapozew do wręczenia P. Mier } \\
\text { Ambasadorowi Austriackiemu przy Dworze } \\
\text { Neapolitańskim }\end{array}$ & D[nia] 15 IX an Dep[ar- \\
\hline 2638 & 3 IX 1812 & $\begin{array}{l}\text { Minister Sprawiedliwości } \\
\text { Uprasza M[ministra] S[ekretarza] S[tanu] } \\
\text { oprzedsięwzięcie kroków do wręczenia zapo- } \\
\text { zwu wprawie W. Franciszkiey z Stawskich } \\
\text { H[...] przeciwko sukcesorom Jana Hrabi } \\
\text { Miera. JW. Felixowi Hrabiemu Mier Amba- } \\
\text { sadorowi Dworu Austriackiego w Neapolu }\end{array}$ & \\
\hline
\end{tabular}

Źródło: AGAD, SSKW, sygn. 28.

Na posiedzeniu Rady Stanu każdy minister przedstawiał projekt urządzenia względem swojego wydziału, który następnie musiał być zatwierdzony przez króla. Ministrowie zwracali się także do króla, prosząc o zatwierdzenie nominacji urzędnika, lub o wyrażenie zgody na urlop, bądź na oddalenie się z Księstwa Warszawskiego na krótki czas ${ }^{92}$. Do tej grupy należały także pisma od saskich ministrów w sprawach związanych z Księstwem Warszawskim oraz pisma kierowane z Warszawy do tychże ministrów.

Memoriały. W Testamencie Politycznym z 1787 roku Fryderyk August rozkazał, aby wszystkie wnoszone do tronu sprawy miały formę tylko pisemną. Powodem wydania takiego nakazu była chęć dokładnego zapoznania się z prośbą do tronu przed podjęciem decyzji oraz oszczędność czasu ${ }^{93}$. Dla memoriałów adresowanych do króla prowadzono osobny rejestr, prowadzony w języku francuskim, używanym powszechnie w kancelarii króla saskiego.

${ }^{22}$ AGAD, RS i RM KW, seria II, sygn. 350, s. 120.

93 W. Hahlweg, dz. cyt., s. 34-35. 
Można zatem traktować ten rejestr jako wzorowany na saskim. W pierwszej rubryce wpisywano numer dziennika ministra.

Rysunek 2. Trecis de Requêtes présentées a La Majeste le Roi

\begin{tabular}{|c|c|c|}
\hline $\begin{array}{c}\text { Object } \\
\text { des Requites }\end{array}$ & $\begin{array}{c}\text { Renseignements et Opinion } \\
\text { du Ministre Secretaire d'Etat }\end{array}$ & Décisions de Sa Majesté le Roi \\
\hline
\end{tabular}

Źródło: AGAD, SSKW, sygn. 5, k. 13-96.

Sposób rozpatrywania memoriałów uregulowano dekretem z dnia 26 stycznia 1808 roku $^{94}$. Obywatele mogli bezpośrednio zwracać się do władcy, kierując do niego pisemną prośbę. Taka prośba mogła dotyczyć m.in. dyspensy ślubnej, zatwierdzenia testamentu, prośby o wsparcie finansowe wdowy, oferowania swoich usług ${ }^{95}$ etc. Pisma z tej grupy były dodatkowo rejestrowane w dzienniku memoriałów.

Zanim pismo przedstawiono królowi, Breza przekazywał je do szefa biura, Stanisława Michalskiego, który rejestrował pismo w Dzienniku Kancelarii Sekretariatu Stanu (Rysunek 3).

Rysunek 3. Dziennik Kancelarii Sekretariatu Stanu

\begin{tabular}{|c|c|c|c|c|c|c|}
\hline $\mathrm{Nr}$ & $\begin{array}{c}\text { Datum } \\
\text { Exhibiti }\end{array}$ & $\begin{array}{c}\text { Treść } \\
\text { podania }\end{array}$ & Referent & $\begin{array}{c}\text { Datum } \\
\text { Rezolucji }\end{array}$ & $\begin{array}{c}\text { Treść Rezolucji } \\
\text { czyli Dekretu }\end{array}$ & $\begin{array}{c}\text { Akta do których } \\
\text { Pieca }{ }^{1} \text { wzięte }\end{array}$ \\
\hline
\end{tabular}

1 Piece (z j. fr.) - akt, dokument, kawałek.

Źródło: AGAD, SSKW, sygn. 25.

Następnie pismo przekazywano sekretarzowi tajnemu, aby - po zapoznaniu się z treścią - sporządził do niej komentarz. Sekretarz tajny w dzienniku ministra i dzienniku kancelarii podpisem potwierdzał otrzymanie pisma.

Kiedy przygotowano pisemny komentarz do pisma, wtedy na audiencji komplet akt przekazywano królowi w celu dokonania dekretacji, którą odnotowywał minister we właściwym rejestrze. Dalszy obieg pisma mógł wyglądać następująco:

94 AGAD, SSKW, sygn. 15, s. 81.

95 W ten sposób Stanisław Michalski został zatrudniony w Sekretariacie Stanu. 
1) Król zatrzymywał pismo, aby rozważyć przedstawioną mu sprawę. $\mathrm{Na}$ kolejnej audiencji minister krótko ustnie referował, na podstawie rejestru i komentarza, wcześniej złożone pismo. Król, podjąwszy decyzję, dyktował rezolucję.

W ten sposób, każda sprawa trafia do mnie [Fryderyka Augusta - PŁ] dwukrotnie, w razie gdybym miat watpliwość, jaka powinna być treść stusznej rezolucjį ${ }^{9}$.

Następnie minister przekazywał do kancelarii zalecenia króla, celem sporządzenia konceptu. Jeden z sekretarzy tajnych sporządzał koncept, wówczas kancelista przygotowywał czystopis. Nie wyklucza to sporządzania czystopisu również przez samego sekretarza tajnego. Sekretarz, odpowiedzialny za zgodność treści pisma z treścią rezolucji królewskiej, kontrasygnował pismo, stawiając w prawym dolnym rogu swój inicjał. Nie wszystkie oryginały i kopie dekretów posiadają tego typu adnotacje. Z kolei żaden z inicjałów nie wskazuje na Brezę. Można przypuszczać, że za sporządzenie pisma nieposiadającego inicjałów sekretarzy odpowiadał minister.

W przypadku, kiedy król miał uwagę do tekstu, wówczas własnoręcznie nanosił poprawki ${ }^{97}$. Fryderyk August znał język polski ${ }^{98}$, więc mógł osobiście sprawdzać, czy tekst aktu jest zgodny z jego wolą.

W Testamencie Politycznym, który stanowił instrukcje dotyczące organizacji funkcjonującego gabinetu saskiego, Fryderyk August stwierdzał, że akt podpisuje najpierw minister gabinetowy, a następnie władca składa własnoręczny podpis ${ }^{99}$. Należy uznać, że w aktach przedstawianych przez ministra Brezę księciu warszawskiemu kolejność podpisów była odwrotna w stosunku do kolejności przyjętej w saskiej kancelarii. Monarcha składał własnoręczny podpis, następnie minister sekretarz stanu kontrasygnował akt oraz przykładał pieczęć gabinetową. $\mathrm{Na}$ podpisanym akcie minister nanosił w prawym górnym rogu kolejny numer dekretu, z kolei w lewym dolnym rogu sy-

96 W. Hahlweg, dz. cyt., s. 34.

97 AGAD, SSKW, sygn. 11, nr 597.

98 Polska w 1811 i w 1813 roku, k. 24. Także: J. Willaume, dz. cyt., s. 292.

99 W. Hahlweg, dz. cyt., s. 35. 
gnaturę ze swojego dziennika, pod którym zarejestrowano pismo, dla którego dekret stanowił odpowiedź.

Kolejną czynność wykonywał protokolista, wpisując pod nadzorem ministra sekretarza stanu pełny tekst dokumentu królewskiego do Protokotu Sekretariatu Stanu. Protokół Sekretariatu Stanu to księga, za którą także odpowiadał na mocy dekretu minister sekretarz stanu. W artykule 76 dekretu z dnia 20 kwietnia 1808 roku stanowiono, że do tej księgi każdy oryginał dokumentu królewskiego pod jego [ministra - PŁ] okiem wpisany być powinien ${ }^{100}$. Protokół Sekretariatu Stanu nie był protokołem z przebiegu posiedzeń ciała kolegialnego. Był oprawną w skórę księgą wpisu, do której wpisywano pełny tekst każdego wydanego przez króla dekretu. Dokument królewski otrzymywał niepowtarzalny numer kolejny, niezależnie od przedmiotu sprawy, rejestrowany na marginesie protokołu i odnotowywany na oryginale aktu.

Wskazany przez szefa kancelarii sekretarz sporządzał urzędowe kopie dokumentów królewskich, które ekspediowano z kancelarii. Kopie te w nagłówku miały tytuł Wypis z Protokotu Sekretariatu Stanu. Na dokumencie często składał swój inicjał, również w prawym dolnym rogu. Sporządzony ekstrakt sprawdzał minister sekretarz stanu, a gdy nie miał zastrzeżeń, wówczas uwierzytelniał kopię swoim podpisem i pieczęcią gabinetową.

2) Król, po zapoznaniu się z podaniem do tronu, mógł bez zatrzymywania pisma u siebie:

a) wydać rezolucję w formie dekretu, wówczas obieg pisma pokrywa się z punktem A;

b) przekazać wybranemu ministrowi pismo, memoriał lub podanie wzbudzające wątpliwość, z poleceniem do zdania Rapportu. W takiej sytuacji minister sekretarz stanu opracowywał odezwę do Rady Stanu lub konkretnego ministra, w której wyjaśniał sprawę i przedstawiał wolę króla. Minister, otrzymawszy polecenie, opracowywał komentarz z wyjaśnieniami, który odsyłał z memoriałem do Sekretariatu Stanu. Po ponownym przedstawieniu sprawy król podawał rezolucję. Rezolucja w formie dekretu miała dalszy obieg pisma jak wyżej;

100 Dekret o organizacji ministerstw, s. 74. 
c) skierować memoriał do konkretnego wydziału, bez dodatkowych adnotacji. Minister Breza sporządzał odezwę do ministra, wyrażając wolę króla załatwienia przez niego sprawy101. Minister wydziałowy odpowiadał za dalszy tok postępowania. Dopiero gdy miał wątpliwość lub nie było właściwej regulacji prawnej, mógł zwrócić się do króla.

Kopię urzędową decyzji królewskiej lub odezwę umieszczoną w kopercie zamykano pieczęcią urzędową ministra. Ekspedycję przekazywano sekretarzowi odpowiedzialnemu za nią. Pismo z należną opłatą przekazywano sztafecie pocztowej.

W archiwum składano pismo, które wpłynęło, koncept i notę o sposobie załatwienia sprawy oraz oryginał dekretu, jeśli takowy wystawiono. Sekretarz archiwista Michał Hube rejestrował pismo w Dzienniku Gtównym Archiwum Księstwa Warszawskiego, nadając kolejny numer z tego dziennika (Rysunek 4).

Rysunek 4. Dziennik Główny Archiwum Księstwa Warszawskiego

\begin{tabular}{|c|c|c|c|c|c|c|c|}
\hline $\mathrm{Nr}$ & $\begin{array}{c}\text { Datum } \\
\text { Exhibiti }\end{array}$ & $\begin{array}{c}\text { Nazwisko } \\
\text { podającego }\end{array}$ & $\begin{array}{c}\text { Treść } \\
\text { podania }\end{array}$ & Referent & $\begin{array}{c}\text { Data } \\
\text { Rezolucji }\end{array}$ & $\begin{array}{c}\text { Treść } \\
\text { Rezolucji } \\
\text { czyli } \\
\text { Dekretu }\end{array}$ & $\begin{array}{c}\text { Akta } \\
\text { do których } \\
\text { Pieca wzięte }\end{array}$ \\
\hline
\end{tabular}

Źródło: AGAD, SSKW, sygn. 26.

Warto zwrócić uwagę, że w dzienniku ministra, dzienniku szefa biura i dzienniku archiwisty wpisywano: regest podania, nazwisko sekretarza referenta oraz regest dekretu i jego numer. Zdarzało się, że w dzienniku archiwisty odnotowywano tylko numer dekretu królewskiego, bez regestu.

Skoro memoriały rejestrowano osobno, również archiwista prowadził rejestr na potrzeby archiwum. Dziennik prowadzony w języku polskim zbliżony był w formie do pozostałych pomocy kancelaryjnych, prowadzonych w Sekretariacie Stanu.

Trudno jest określić, w jakim porządku składano akta w archiwum. Jednak skoro ani w dziennikach, ani w dekretach, ani w protokole nie wprowadzono układu rzeczowego lub chronologicznego, prawdopodobny jest układ

101 AGAD, RS i RM, seria II, sygn. 351, s. 7-8. 
kolejności przekazywania akt do archiwum. Prawdopodobny jest także układ alfabetyczny według nazwisk osób - suplikantów. Niestety nie można stwierdzić tego jednoznacznie.

Tabela 7. Dziennik podanych bezpośrednio do Najjaśniejszego Pana Memoriałów

\begin{tabular}{|c|c|c|c|c|c|}
\hline $\begin{array}{c}\text { Numer } \\
\text { Memoriału }\end{array}$ & $\begin{array}{c}\text { Nazwisko } \\
\text { podającego } \\
\text { i mieszkanie }\end{array}$ & $\begin{array}{c}\text { Treść } \\
\text { podania }\end{array}$ & $\begin{array}{c}\text { Zostało } \\
\text { odesłane }\end{array}$ & $\begin{array}{c}\text { Treść rezolucji } \\
\text { data niemniej } \\
\text { zapisanie } \\
\text { zdanego raportu }\end{array}$ & $\begin{array}{c}\text { W aktach } \\
\text { suplikantów } \\
\text { na stronie }\end{array}$ \\
\hline 1486 & $\begin{array}{c}\text { Hr: de Breze } \\
\text { Lanckoroński } \\
\text { dawniej Ge- } \\
\text { nerał Major } \\
\text { Wojk Pol- } \\
\text { skich }\end{array}$ & $\begin{array}{c}\text { 22 grudnia } \\
1812 \text { o } \text { udzie- } \\
\text { lenie.. }\end{array}$ & $\begin{array}{c}\text { NN Pana } \\
\text { po reprodukcji, } \\
\text { wskazane do akt }\end{array}$ & \\
\hline
\end{tabular}

${ }^{1}$ Suplikantem nazywano osobę zwracającą się do urzędu.

2 (...) o udzielenie sobie Urzędu Dyrektora Poczt Księstwa Warszawskiego: niemniej o nadanie sobie w nagrodę dawnych zasług starostwa Liwskiego prawa dziedzictwa, które trzyma jako nabyte na dożywocie.

Źródło: AGAD, SSKW, sygn. 5, k. 1-12, 97 i nn.

Podobnie jak w archiwum Królestwa Saskiego, również w archiwum Księstwa Warszawskiego gromadzono i przechowywano oryginały decyzji króla, akta suplikantów i inne związane z funkcjonowaniem Sekretariatu. Fryderyk August zalecił archiwiście saskiemu prowadzenie Volumini Actorum. Była to księga, w której wpisywano krótkie recenzje treści, czyli regesty akt przechowywanych $\mathrm{w}$ archiwum ${ }^{102}$. Miała umożliwić szybsze odnalezienie konkretnej decyzji króla w aktach. W archiwum polskim prowadzono sumariusz dekretów królewskich, w którym wpisywano regesty decyzji władcy. Z zapisów można rozpoznać więcej niż jedną rękę pisarza. Mógł go prowadzić pomagający registratorowi kancelista lub jeden z sekretarzy kancelarii.

102 W. Hahlweg, dz. cyt., s. 29-30. 
Tabela 8. Sumariusz Dekretów Królewskich

\begin{tabular}{|c|c|l|l|l|}
\hline $\begin{array}{c}\text { Numer } \\
\text { Dekretu }\end{array}$ & $\begin{array}{c}\text { Numer } \\
\text { Journalu }\end{array}$ & \multicolumn{1}{|c|}{ Data } & \multicolumn{1}{|c|}{ Treść Dekretu } & Annotacjo \\
\hline 3229 & 20 & $\begin{array}{l}26 \text { IX } \\
1811\end{array}$ & $\begin{array}{l}\text { Najjaśniejszy Pan dozwala aby PP Tarczyński } \\
\text { i Czaplicki Archiwariusze dozór nad dawnemi } \\
\text { Aktami polskiemi w Poznaniu mający rocznie } \\
\text { zł } 600 \text { pensji pobierali }\end{array}$ & \\
\hline 3475 & $413 \mathrm{~A}$ & $\begin{array}{l}12 \mathrm{XI} \\
1811\end{array}$ & $\begin{array}{l}\text { Uniwersał zwołujący posłów i deputowanych } \\
\text { na Sejm }\end{array}$ & \\
\hline 3935 & 1284 & $\begin{array}{l}4 \mathrm{III} \\
1812\end{array}$ & $\begin{array}{l}\text { Potwierdzenie Etatu Pensji i Wydatków dla kance- } \\
\text { larii Rady Ministrów }\end{array}$ & \\
\hline 4457 & 2269 & 12 VII & $\begin{array}{l}\text { Najjaśniejszy Pan przystępuje do Konfederacji } \\
\text { Generalnej Polski }\end{array}$ & \\
\hline
\end{tabular}

Źródło: AGAD, SSKW, sygn. 9 (1811-1813); sygn. 10 (1809-1811)

W pierwszej rubryce wpisywano niepowtarzalny numer każdego dekretu królewskiego, nadawany przed wpisem treści do protokołu. Druga rubryka stanowiła odesłanie do dziennika ministra, była to sygnatura z dolnego lewego rogu dekretu. W trzeciej rubryce zamieszczano regest dekretu. Ostatnia rubryka pozostawała pusta. Daty końcowe wskazują na prowadzenie trzech tomów sumariusza. Niestety nie zachował się tom pierwszy. Jednak przejrzenie dwóch tomów dostępnych wskazuje na więcej niż jedną rękę pisarza sumariusza. Również regesty zdarzają się mniej lub bardziej lakoniczne.

Powyższy przegląd pomocy ewidencyjnych kancelaryjnych i archiwalnych sugeruje dbałość o rejestrację i losy pisma na poszczególnych etapach jego życia.

\section{ANALizA STYLU, FORMY I TREŚCI AKT}

W swoim artykule Waldemar Chorążyczewski podaje funkcje dokumentu, z których podstawową było upamiętnienie pojedynczej czynności prawnej. Dokument to także manifestacja władzy monarchy. Jednak najważniejszą funkcją nowożytnego dokumentu było stanowienie narzędzia władzy i administracji. Dokument, czyli komunikat, mógł być rozkazem - mandatem, roz- 
porządzeniem - edyktem, rozstrzygnięciem - dekretem, wreszcie nadaniem w zakresie kompetencji królewskich ${ }^{103}$.

Jak zauważył Sobociński, wszystkie dokumenty królewskie Fryderyka Augusta, niezależnie od przedmiotu rozstrzyganej sprawy, prywatnej czy państwowej, nazywane były dekretami ${ }^{104}$. Jednak obywatele Księstwa Warszawskiego nazywali decyzje królewskie zwyczajowo wyrokami ${ }^{105}$. W okresie przedrozbiorowym mianem dekretu nazywano wyroki sądowe, które często wpisywane były w tzw. dekretarz ${ }^{106}$. Nie wszystkie decyzje księcia warszawskiego były wyrokami ${ }^{107}$, lecz wyrażały wolę króla, stanowiły rozstrzygnięcia. Choć w znaczeniu szerokim w Księstwie Warszawskim używano określenia dekret, to jednak już w akcie dotyczącym organizacji ministerstw dokonano dookreślenia, wyróżniając: prawa, dekrety, reskrypty i rozkazy królewskie $(\operatorname{art} .75)^{108}$.

W okresie panowania Fryderyk August książę warszawski wydał 5136 dekretów $^{109}$. Pomijamy tutaj dekrety wydane przez Radę Ministrów w imieniu króla. Cechą wspólną dekretów był uroczysty formularz nagłówka z intytulacją i datacją, odbijany na papierze za pomocą sztychu. Podczas kwerendy archiwalno-bibliotecznej nie udało się dotrzeć do wystawionych przez Fryderyka Augusta dokumentów innych niż papierowe. Nie wyklucza to możliwości wystawienia dokumentu pergaminowego, jednak w tym miejscu nie zostanie to rozstrzygnięte.

103 W. Chorążyczewski, Nowożytny dokument królewski. Możliwości badawcze, [w:] Polska kancelaria królewska czasów nowożytnych między wtadzą a spoteczeństwem, pod red. W. Chorążyczewskiego i W. Krawczuka, Toruń 2003, s. 29-30.

104 W. Sobociński, dz. cyt., s. 32.

105 Towarzystwo Królewskie Przyjaciót Nauk 1800-1832, Księga II: Czasy Księstwa Warszawskiego 1807-1815, oprac. A. Kraushar, t. 1, Warszawa 1902, s. 101.

106 Dekretarz, [w:] Encyklopedia staropolska, oprac. Z. Gloger. [on-line] Dostęp na World Wide Web (2 VI 2009 r.): http://univ.gda.pl/-literat/glogers/0007.htm.

107 Wyrokiem nazwano akt łaski dla skazańca. Por. AGAD, Sekretariat Stanu, sygn. 11, nr 565.

${ }^{108}$ Dekret o organizacji ministerstw, s. 74.

109 AGAD, SSKW, sygn. 9. 
Rysunek 5. Nagłówek oryginałów dekretów królewskich

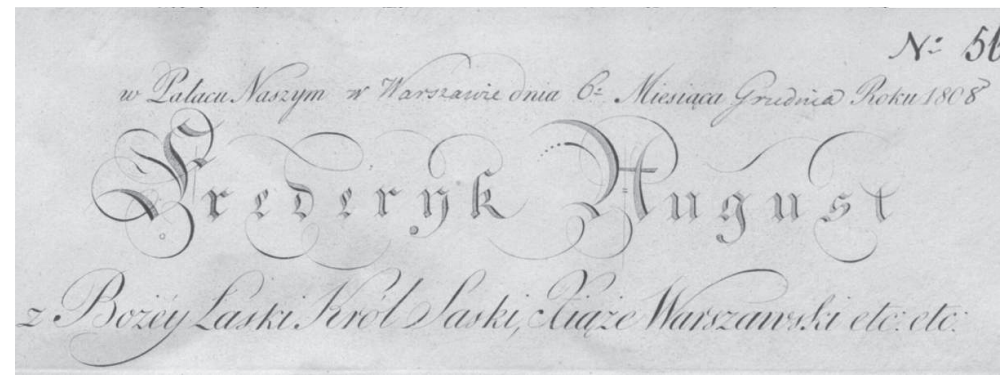

Źródło: AGAD, Sekretariat Stanu, sygn. 11.

Rysunek 6. Nagłówek urzędowej kopii dekretów królewskich

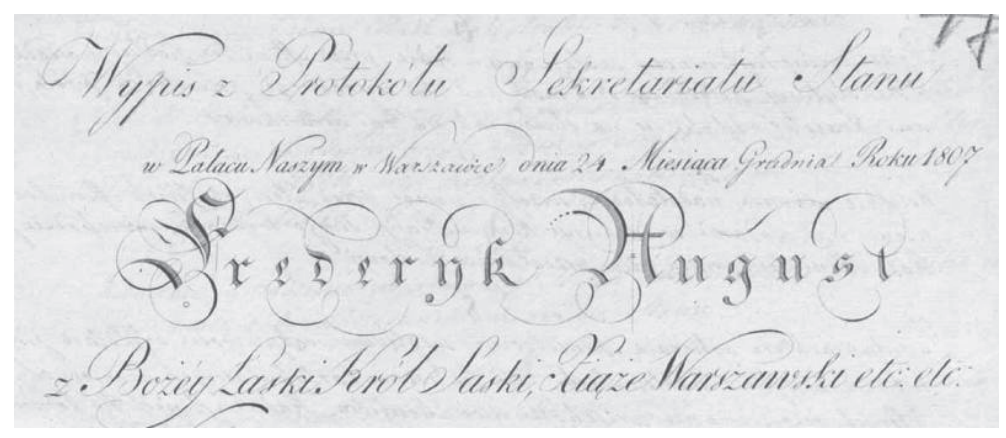

Źródło: AGAD, RM i RS KW, seria II, sygn. 3, s. 2.

Z powyższych uwag wstępnych wyłaniają się dwa główne problemy związane z dokumentami królewskimi przygotowywanymi w Sekretariacie Stanu Księstwa Warszawskiego. Pierwszy dotyczy właściwego rozróżnienia typów akt spośród dekretów królewskich, ponieważ nie były one wystawiane w jednakowym stylu. Jakkolwiek ze względu na masowość akt i powtarzalność pewnych czynności prawnych stosowano podobne formularze dokumentów. Drugi problem to stosunek władcy i społeczeństwa do oryginału i kopii urzędowej dokumentu królewskiego, stanowiącego formę komunikacji pomiędzy władcą a poddanymi. 
Przejdźmy zatem do klasyfikacji dekretów królewskich, czyli dokumentów. Według Meisnera, który badał kancelarię władcy pruskiego, w zarządzeniach monarchy można wyróżnić, według stylu, następujące typy aktów ${ }^{110}$ :

a) Dokumenty z pełnym formularzem (lettre de cérémonie) ${ }^{111}$ :

Reskrypty (modus rescripti/mandati) - zarządzenia królewskie z pełną intytulacją w nagłówku, z narracją subiektywną (My);

Patenty - forma zbliżona do reskryptu; patenty nominacyjne odnosiły się do władcy w stylu My, zaś do zainteresowanego w trzeciej osobie;

b) Dekrety/Rezolucje (modus decreti) - pisane w trzeciej osobie z narracją obiektywną (stilo relativo); rozstrzygnięcia władz wyższej instancji;

c) Autografy (modus litterarum) - najmłodsza forma aktowa z omówionych powyżej, własnoręcznie podpisywana przez władcę, wystawiana w jego prywatnym biurze; mniej oficjalny i mniej uroczysty styl, skrócona intytulacja, forma $\mathrm{Ja}$.

Jak zauważa Chorążyczewski, subiektywna narracja dokumentu (a) stanowi nawiązanie do typowej dawnej formy dyplomu. Z kolei narracja obiektywna (b), bezosobowa, jest elementem nowoczesnego aktu administracyjnego $^{112}$. W przypadku pozostałości aktowej Sekretariatu Stanu nie znajdziemy książęcych dokumentów modus litterarum.

Wśród dekretów, czyli rozstrzygnięć Fryderyka Augusta ${ }^{113}$, możemy wyróżnić:

1) akty stanowiące prawa

a) ustawy sejmowe, których oryginały przechowywano w archiwum sejmowym, przykładano do nich pieczęć wielką stanu; kontrasygnowane przez właściwego ministra

${ }^{110}$ H. O. Meisner, Aktenkunde, Berlin 1935, s. 16-30.

111 W kancelarii władcy pruskiego zdarzało się, że reskrypty stanowiące prawa nie miały formuły promulgacyjnej, ale zamieszczano ją na pismach kierowanych do pojedynczych osób. Por. tamże, s. 18.

112 W. Chorążyczewski, R. Degen, Kancelarie „wtadców” polskich XIX i XX wieku. Rekonesans badawczy, [w:] Bellicum Diplomaticum II Thorunense, pod red. W. Chorążyczewskiego i J. Tandeckiego, Torun 2007, s. 141.

113 Podano typy dokumentów oraz ich przykłady. W Aneksach zamieszczono uroczyste dekrety, z zachowaniem prawideł języka staropolskiego, które wręczano $\mathrm{z}$ własnoręcznym podpisem króla. 
b) dekrety, czyli rozporządzenia

c) ustawy dopełniające konstytucję, które w narracji mają odwołanie do ustawy zasadniczej - cecha aktu administracyjnego ${ }^{114}$

d) ustawy księcia stanowiące prawa, często z rozbudowaną narracją

2) rozkazy czyli mandaty

a) uniwersały

b) nominacje, w tym:

- prezenty duchownych katolickich, np.

W Pałacu Naszym w Warszawie dnia 24 miesiąca grudnia 1807 roku

Fryderyk August, z Bożej łaski król saski, książę warszawski etc. etc.

Po śmierci Księdza Jana Waleszyńskiego na wakujaca Plebanię w Dobrach Naszych Kowalewie, w Archidiecezji Gnieźnieńskiej Prawa Kollacji Naszej, umyśliliśmy mianować zaleconego nam z przymiotów i zdatności, Księdza Wojciecha Łęskiego jakoż Go niniejszem mianujemy mieć chcac; ażeby przez Najprzewielebniejszego Księcia Arcybiskupa lub urząd jego zastępczy na tej Plebanii byt osadzonym.

Uwiadomienie o tej Woli Naszej Najprzewielebniejszego Arcybiskupa Gnieźnieńskiego lub Urzędu Jego Zastępczego, Ministrowi Spraw Wewnętrznych i Religijnych zalecamy ${ }^{115}$.

Podpisano Fryderyk August przez króla minister sekretarz stanu Stanisław Breza

- patenty na urzędy, np.

W Pałacu Naszym w Warszawie dnia 8 miesiąca grudnia 1808 roku

Fryderyk August, z Bożej łaski król saski, książę warszawski etc. etc.

Gdy podtug raportu Ministra Policji uczynionego Nam pod dniem Gym Miesiąa teraźniejszego, Franciszek Remus nominowany Dekretem Naszym Burmistrzem do Miasta Więcborga w Departamencie Bydgoskim za

114 W. Chorążyczewski, R. Degen, dz. cyt., s. 141.

115 AGAD, SSKW, sygn. 15, s. 53. 
ten Urząd podziękowat mianujemy na jego miejsce Burmistrzem do Miasta Więcborga Kajetana Rożyńskiego.

Wyżej mianowany dla którego później nominację szczególna wydać rozkażemy na wskazany sobie Urzad wezwany i $w$ nim instalowany być ma. Dopetnienie niniejszej Naszej Ustawy Ministrom Spraw Wewnętrznych i Policji Księstwa Naszego Warszawskiego zalecamy ${ }^{116}$

Podpisano Fryderyk August przez króla minister sekretarz stanu Stanisław Breza

- patenty rzemieślnicze, np.

W Pałacu Naszym w Dreźnie dnia 12 miesiąca kwietnia 1808 roku

Fryderyk August, z Bożej łaski król saski, książę warszawski etc. etc.

Chcąc okazać Nasza troskliwość o podźwignienie fabryk w Księstwie Naszym Warszawskim i zachęcić wyszczególniająca się zdatność do rękodziet krajowi potrzebnych, postanowiliśmy mianować dobrze Nam zaleconego z swej zdatności Siodlarza Jana Gottfryda Krause Naszym Siodlarzem Nadwornym w Księstwie Warszawskim, jakoż rzeczonego Jana Gottfryda Krause Naszym Siodlarzem Nadwornym w Księstwie Warszawskim niniejszem mianujemy, chcąc mieć: aby takowego Tytutu z szczególnych względów Naszych mu udzielonego, bez nadwerężania jednak praw krajowych z innych Obowiazków swoich wszędzie używat.

Dopetnienie tej Naszej Woli Naszemu Ministrowi Spraw Wewnętrznych zalecamy ${ }^{117}$.

Podpisano Fryderyk August

przez króla minister sekretarz stanu Stanisław Breza

- patenty na pastora, np.

W Pałacu Naszym w Dreźnie dnia 7 miesiąca listopada 1808 roku

Fryderyk August, z Bożej łaski król saski, książę warszawski etc. etc.

116 Tamże, sygn. 11, nr 569.

117 Tamże, sygn. 15, s. 167. 
Wszem wobec i każdemu z osobna wiadomo czyniemy: iż przychylajac się do przetożenia Ministra Naszego Wewnętrznego i Religijnego po dobrowolnem odstapieniu Pastora Struwe $w$ Grębocinie przy Toruniu w Departamencie Bydgoskim na zawakowany tamże przy Kościele Ewangelicko-Augsburskim Urząd rzeczonego Pastora prawa Kollacji Naszej, Zaleconego Nam z przymiotów i zdatności P[an]a Pasternaci, tymczasowego pastora i rektora ordynowanego z Ptocka mianujemy mieć chcac, ażeby zwyczajem $w$ Zgromadzeniach tego wyznania używanym, tenże prezentowany, na wspomnianym Urzędzie Pastora byt osadzonym.

Niniejszej Woli Naszej ogtoszenie Ministrowi Naszego Wewnętrznemu i Religijnemu polecamy ${ }^{118}$.

Podpisano Fryderyk August

przez króla minister sekretarz stanu Stanisław Breza

c) zalecenia, upoważnienia, np.

W Pałacu Naszym w Warszawie dnia 19 miesiąca listopada 1808 roku

Fryderyk August, z Bożej łaski król saski, książę warszawski etc. etc. Na przedstawiony Nam przez Radę Stanu pod dniem 11 teraźniejszego miesiaca raport Generata Kosińskiego pod data z Częstochowy dnia 9 listopada roku bieżacego, w którym tenże Generat donosi o nowych między sobą a Komisarzem Pruskim przy rozmiarze okolicy Byczyny nastapionych porach potwierdzamy opinia Rady Naszej Stanu, iż najdogodniej będzie gdy Generat Kosiński zostawiając okoliczności wyrażone w powyższym raporcie i im podobne, do ostatecznego między Dworami porozumienia się, powierzona sobie czynność demarkacyjna dalej prowadzić będzie i zalecamy tejże Radzie Stanu, aby stosowna do niniejszej Naszej Decyzji przestata Generatowi Kosińskiemu informację ${ }^{119}$.

Podpisano Fryderyk August przez króla minister sekretarz stanu Stanisław Breza

3) dyspensy małżeńskie lub na zarządzanie majątkiem, np.

W Pałacu Naszym w Warszawie dnia 18 miesiąca listopada 1808 roku

118 Tamże, sygn. 15, s. 413.

119 Tamże, sygn. 11, nr 532. 
Fryderyk August, z Bożej łaski król saski, książę warszawski etc. etc.

Przychylając się do przetożeń podanych Nam przez Naszego Ministra Sprawiedliwości stosownie do Artykutu 145 Kodeksu Cywilnego Napoleona i uważają za ważne powody Nam przedstawione, udzielamy niniejszem Annie Barbarze Thimm we wsi Wildzie Departamencie i Powiecie Poznańskim zamieszkatej, lat 13 miesięcy 11 liczącej, dyspensę co do wieku, chcąc iżby ta od wtadz wtaściwych za zdolna do zawarcia matżeńskiego zwiazku uważana byta, skoro to jest z wola owdowiatej jej Matki.

Dopetnienie niniejszej Naszej Woli Ministrowi Sprawiedliwości Księstwa Naszego Warszawskiego zalecamy ${ }^{120}$.

Podpisano Fryderyk August

przez króla minister sekretarz stanu Stanisław Breza

4) akty łaski królewskiej

a) ułaskawienie (ius agratiandi), np

W Pałacu Naszym w Warszawie dnia 21 miesiąca grudnia 1807 roku

Fryderyk August, z Bożej łaski król saski, książę warszawski etc. etc.

Chcąc przy początkowem obejmowaniu Rządów nad ludami Księstwa Warszawskiego, Easki Naszej Królewskiej okazać dowody oświadczamy niniejszem, iz mając sobie od Ministra Naszego Sprawiedliwości podanych więźni końcem zwolnienia lub zupetnego opuszczenia im kar, wnadziei że przez dobre sprawowanie się uczyniq na dal życia poprawe; postanowiliśmy przychylić się do przetożeń w tej wierze Nam uczynionych jakoż przychylając się udzielamy Easkę Nasza Królewska, moca Nam stużaca, dla przedstawionych Nam więźniów Departamentu Bydgoskiego, z których liczby Franciszka Leszczka i wspólnictwo zabójstwa dwóch ludzi obwinionego, ponieważ nie należat do zabójstwa, lecz tylko dopomagat do pochowania zabitych i zbrodnie tę trzymat w sekrecie, od dalszego więzienia kary uwalniamy Franciszka Leszczka. Niniejszej Woli Naszej ogtoszenie Ministrowi Naszemu Sprawiedliwości polecamy ${ }^{121}$.

Podpisano Fryderyk August

przez króla minister sekretarz stanu Stanisław Breza

120 Tamże, sygn. 11, nr 528.

121 Tamże, sygn. 15, s. 41-42. 
b) odpowiedź na memoriał, np. W Pałacu Naszym w Warszawie dnia 29 miesiąca listopada 1808 roku

Fryderyk August, z Bożej łaski król saski, książę warszawski etc. etc.

Przychylając się do prośby Petroneli Zardeckiej wdowy po kapitanie niegdyś wojsk polskich, i przez wzglad na stan jej wsparcia potrzebujacy upoważniamy Naszego Ministra Skarbu Księstwa Warszawskiego ażeby pomienionej wdowie Petroneli Zardeckiej sposobem gratyfikacji, na ten jeden raz wyliczyt ze Skarbu publicznego ztotych polskich sześćset.

Dopetnienie tej Naszej Woli Naszemu Ministrowi Skarbu Księstwa Warszawskiego zalecamy ${ }^{122}$.

Podpisano Fryderyk August przez króla minister sekretarz stanu Stanisław Breza

c) przywileje

- nadanie tytułu królewskiego, np.

W Pałacu Naszym w Dreźnie dnia 12 miesiąca maja 1812 roku

Fryderyk August, z Bożej łaski król saski, książę warszawski etc. etc.

Chcac nadgrodzić usitowania P [an] a Samuela Bruschke, który znacznym naktadem dżwignąt i znakomicie udoskonalit fabrykę papieru w Jeziernie, niemniej zachęcić go do coraz większych okoto wzrostu tejże fabryki zabiegów; nadajemy niniejszem wymienionej fabryce tytut "uprzywilejowanej królewskiej fabryki papieru", chcac aby zaszczytu tego z szczególnych Naszych wzgledów sobie udzielonego używata, bez nadwerężenia jednak praw krajowych.

Uwiadomienie pomienionego P[an] a Bruschke o tej Naszej Easce Ministrowi Naszemu Spraw Wewnętrznych polecamy ${ }^{123}$.

Podpisano Fryderyk August

przez króla minister sekretarz stanu Stanisław Breza

- dyplom nobilitacji

- list indygenatu

122 Tamże, sygn. 11, nr 550.

123 Tamże, sygn. 20, s. 576-577. 
- dyplom na medalion, np.

W Pałacu Naszym w Warszawie dnia 30 miesiąca grudnia 1808 roku

Fryderyk August, z Bożej łaski król saski, książę warszawski etc. etc.

Wszem wobec komu o tem wiedzieć należy, wiadomo czynimy: w celu zadośćuczynienia przyrzeczeniom przez bywsza Komisje Rządząca, chcąc dać dowód Easkawości Naszej dla tych którzy na Urzędzie Sędziego Pokoju najszczęśliwszemi $w$ zagodzeniu spraw okazali się, i najwięcej onychże zatatwiając spokojność Naszym mitym i wiernym Poddanym wrócili, przeznaczyliśmy Medalion, który dozwalamy, ażeby mógt bydź noszony na lewym boku na wstążce niebieskiej, dla pamiątki i jasnego dowodu zastużonego w Departamencie Obywatela na Urzędzie Sędziego Pokoju. Mając Sobie przedstawionem, $i \dot{z} w$ Departamencie Ptockim najwięcej zagodzit spraw Urodzony Chetmicki, dalismy rozkaz Ministrowi Naszemu Sprawiedliwości, żeby przestat ten dowód Łaski Naszej wspomnianemu Urodzonemu Chetmickiemu i chcemy żeby byt uważany za ozdobionego tym medalionem, którego napis zaszczyt noszq̨cemu przynosi i Naszej Łaski jest dowodem ${ }^{124}$.

Podpisano Fryderyk August przez króla minister sekretarz stanu Stanisław Breza

Powyżej zaprezentowano próbki reprezentacyjne dokumentów księcia warszawskiego oraz ich typologię. Ze względu na masowość akt nie przeprowadzono szczegółowej analizy dyplomatycznej wszystkich dokumentów królewskich. Jednak warto zastanowić się nad pewnymi prawidłami lub ich brakiem. Przejdźmy zatem do podsumowania.

Jedynym typem dokumentów, w których zamieszczono inwokację Wimię Pańskie Amen, są dyplomy nobilitacji. Wystawiono dziewięć dyplomów nobilitacji i nadania herbu z podpisem i pieczęcią księcia warszawskiego:

- w 1810 roku dla W. Putrowa i G. Stremlena ${ }^{125}$,

124 Tamże, sygn. 15, s. 511.

125 Tamże, sygn. 10, k. 148. 
- w lutym 1811 roku dla Detera, Nehringa i Mohldorffa,

- w marcu 1811 roku dla S. Tschepe ${ }^{126}$,

- w czerwcu 1811 roku dla A. Grzędzińskiego ${ }^{127}$, L. Parpart ${ }^{128}$ i J. Kuźnicza $^{129}$.

Kolejna rzecz, która zwraca uwagę, to promulgacja, a właściwie jej brak w większości dokumentów. Formułę Wszem wobec komu o tem wiedzieć należy, wiadomo czynimy zawiera uniwersał oraz dyplom na medalion sędziego pokoju. Nieco dziwi fakt umieszczenia tej formuły na patentach na pastora, a pominięcia jej na innych nominacjach na urzędy. Bardziej uroczysta promulgacja występuje na dyplomach nobilitacji Wiadomo czynimy wszystkim teraźniejszym i przysztego wieku ludziom. Promulgacja również stanowiła podkreślenie uroczystości wystawianego dokumentu.

Wyróżnieniem dokumentu było umieszczenie narracji mniej lub bardziej rozbudowanej. Zwraca uwagę rozbudowana narracja na akcie nadania przywileju Towarzystwu Warszawskiemu Przyjaciół Nauk oraz w uniwersale. Bardziej zwięzłą narrację spotkamy na wielu dokumentach królewskich, czasem jest to jedno zdanie. Cechą wspólną wszystkich dokumentów królewskich jest subiektywna narracja, która przechodzi w narrację obiektywną.

Elementem występującym wyjątkowo na pojedynczych dokumentach Fryderyka Augusta jest korroboracja. Na mocy dekretu królewskiego pieczęć gabinetowa miała być przykładana do wszystkich dokumentów królewskich, zatem nie było koniecznym stwierdzanie tego faktu w treści. Jakkolwiek, zamieszczenie tej formuły stanowiło wyróżnienie i podniosłość wystawionego dokumentu. Korroboracja występuje na dyplomach nobilitacji oraz na akcie przystąpienia Fryderyka Augusta do Konfederacji Generalnej. Na jedynym akcie indygenatu, wystawionego dla hrabiego Senfft de Pilsach, widnieje informacja o przywieszeniu pieczęci wielkiej stanu ${ }^{130}$.

Jak zauważono wyżej, dokumenty księcia warszawskiego miały datację przed intytulacją. Stosowano formularz datacji: w Patacu Naszym ... dnia miesiąca roku. Umieszczenie daty na początku dokumentu stanowi element nowoczesny. Znajdziemy jednak dokumenty królewskie, w których datację zamieszczono zwyczajowo na końcu aktu. Poprzez datację: Dan w Pata-

\footnotetext{
126 Tamże, sygn. 18, s. 433-435.

127 Tamże, sygn. 20, s. 471-473.

128 Tamże, sygn. 20, s. 474-476.

129 Tamże, sygn. 20, s. 638-641.

130 Tamże, sygn. 21, s. 86-88.
} 
cu Naszym w ... dnia miesiąca roku podkreślono uroczystość wystawionego aktu. Tego typu datację znajdziemy na dokumentach z pełnym formularzem, tj. uniwersałach, dyplomach nobilitacji oraz akcie przystąpienia księcia warszawskiego do Konfederacji Generalnej ${ }^{131}$.

Wszystkie dokumenty królewskie opatrzono mandatum in privilegio. Ostanie zdanie odnosi się do konkretnego ministra, który ma dopilnować wykonania woli króla. W przypadku dekretów, w znaczeniu węższym, minister sprawiedliwości otrzymywał rozkaz publikacji aktu w Dzienniku Praw.

Przez użycie pełnego lub skróconego formularza dokumentu podkreślano znaczenie i rangę odbiorcy oraz udzielenie łaski królewskiej. Spójrzmy na sytuację nadania przywileju tytułu królewskiego. Fryderyk August wydał dwa tego typu dekrety: dla Towarzystwa Warszawskiego Przyjaciół Nauk i fabryki papieru. Do grona uczonych król zwraca się bardzo uroczyście, stosując bardziej rozbudowany formularz, zwłaszcza narrację. W przypadku właściciela fabryki okazaniem łaski jest samo nadanie tytułu, a formularz został skrócony.

Dekretem królewskim z kwietnia 1808 roku postanowiono, że odbiorca dokumentu otrzyma zaledwie kopię urzędową w postaci wypisu z protokołu, bez własnoręcznego podpisu władcy. Jeszcze w marcu 1808 roku Rada Stanu skierowała do Fryderyka Augusta prośbę następującej treści:

(...) dla zachowania dawnych krajowych zwyczajów i za stawnej pamięci JKMci używanych, dekrety, reskrypty i patenty królewskie, oprócz zachowanego w archiwum oryginatu, wydawane byty temu, do kogo się ściagaja, z wtasnoręcznym podpisem Najjaśniejszego Pana, co by większa tym aktom nadawato uroczystość i powage; w patentach zaś chlubniejsza dla otrzymujących je zostawiato pamiątkę $e^{132}$.

Choć późniejszy dekret o zadaniach ministra sekretarza stanu sugeruje odrzucenie prośby Rady Stanu, to jednak miały miejsce pewne wyjątki.

Pierwszy taki akt, podpisany 30 kwietnia 1808 roku, wręczony został Towarzystwu Warszawskiemu Przyjaciół Nauk. Na mocy tego dokumentu Towarzystwo uzyskało łaskę króla i stało się Królewskim Towarzystwem Przyjaciół Nauk. Minister Łubieński na posiedzeniu Towarzystwa przekazał jego członkom wyrok, dla większej solenności, wtasnq ręka króla podpisany ${ }^{133}$. Łaską uprzywilejowanej królewskiej fabryki papieru obdarzona została fabryka

131 Tamże, sygn. 21, s. 19-20.

132 Protokoty Rady Stanu Księstwa Warszawskiego, Toruń 1960, s. 181.

133 Towarzystwo Królewskie Przyjaciót Nauk 1800-1832, s. 102. 
w Jeziornie dnia 12 maja 1812 roku $^{134}$. Wyżej zwróciłam uwagę, że dokumenty różniły się formularzem. W tym miejscu istotna jest kolejna różnica znaczenia odbiorcy dokumentu królewskiego. Uczeni otrzymali uroczysty przywilej własnoręcznie podpisany przez króla. Właściciel fabryki otrzymał tytuł, ale dokument był kopią urzędową, sporządzoną w kancelarii ministra spraw wewnętrznych.

Wyjątkową była również sytuacja związana ze zwołaniem sejmu i uniwersałami. Łubieński na prośbę księcia warszawskiego nakazał sporządzić z pomocą Skorochoda Majewskiego, dbającego o akta Metryki Koronnej, wypisy z tych akt. Przedmiotem zainteresowania były odezwy do Senatu oraz do stanu rycerskiego z czasów Rzeczypospolitej. Na podstawie wypisów minister sprawiedliwości przygotował odezwy, listy i uniwersały. Intytulacja i promulgacja są zgodne. W drugim dokumencie w narracji władca odwołuje się do aktów prawnych. Jednak w formułach końcowych również dostrzec można zbieżność. Ten krok zyskał królowi pochwały za znajomość dawnych polskich zwyczajów ${ }^{135}$. Własnoręcznym podpisem księcia warszawskiego opatrzone zostały także ustawy sejmowe.

Do dokumentów, które odbiorca otrzymywał z własnoręcznym podpisem króla, należały dyplomy nobilitacji oraz list indygenatu. Podpis księcia warszawskiego znalazł się także na akcie przystąpienia do Konfederacji Generalnej.

Król zwracał uwagę na zachowanie zwyczajów polskich w kontaktach ze szlachtą, posłami. W zależności od przedmiotu sprawy czy rangi odbiorcy wystawiano oryginał aktu dla odbiorcy, okazując mu szczególną łaskę królewską i szacunek.

Fryderyk August mógł zalecić wręczenie oryginału dokumentu, co stanowiło ponowne okazanie łaski dla odbiorcy. W przypadku patentów wojskowych król nie składał podpisu. Jednak minister wojny na podstawie dekretu sporządzał stosowny dokument na uroczystym formularzu ${ }^{136}$. Z kolei prezenty duchownych stanowiły kopię wypisu z protokołu stanu, potwierdzoną przez ministra spraw wewnętrznych ${ }^{137}$.

134 Tekst cytowany wyżej.

135 Pamiętniki Feliksa hr. Eubieńskiego, s. 196-198.

136 Biblioteka Narodowa, rkps 9601(4)/V, s. 6.

137 Ossolineum, rkps 14187/III, s. 89. 


\section{ZAKOŃCZENIE}

Głównym wyznacznikiem zadań, wykonywanych w Sekretariacie Stanu, były zadania, wynikające z obowiązków ministra sekretarza stanu. Tym obowiązkom podporządkowano system pracy kancelarii. Jakość wykonywanych zadań przy ich nadmiarze pozostawiała czasem wiele do życzenia, ale Sekretariat Stanu stanowił jedyną drogę dla obywateli do skontaktowania się z monarchą.

Gabinet Stanisława Augusta miał wspólne elementy z gabinetem saskim, a Sekretariat Stanu był kancelarią przy saskim królu. Zatem w przypadku tej kancelarii królewskiej możemy spodziewać się raczej kontynuacji wcześniejszych zwyczajów niż wprowadzenia nowej formy akt spraw, charakterystycznej dla XIX wieku. Argumentem przemawiającym za zastosowaniem w Sekretariacie Stanu znanych już rozwiązań jest także fakt, że król saski był niechętny gwałtownym zmianom. Choć w Księstwie Warszawskim wprowadzano nowoczesne rozwiązania ustrojowe i kancelaryjne, to jednak Królestwo Saksonii było w tym okresie bardziej zachowawcze. Fryderyk August ostrożnie podchodził do przeprowadzanych w Księstwie reform i nie zamierzał w krótkim czasie przenosić ich na grunt saski. Jak zresztą napisał biograf saskiego władcy, pośpiech byt rzeczq nieznana $w$ Saksonii ${ }^{138}$. Mogło to także powodować sceptyczne podejście do nowoczesnej kancelarii akt spraw. Zatem Sekretariat Stanu został urządzony ogólnie według rozwiązań XVIII-wiecznych, z uwzględnieniem potrzeb kancelarii do spraw Księstwa Warszawskiego.

Unowocześnienie polskiej kancelarii królewskiej, za jaką należy uznać Sekretariat Stanu Księstwa Warszawskiego, w tym przypadku stanowiły rozbudowane pomoce ewidencyjne. W kancelarii stanisławowskiej dopiero zaczynano wprowadzać dzienniki korespondencyjne ogólne ${ }^{139}$. W Sekretariacie Stanu prowadzono kilka dzienników.

Akt królewski we wszystkich egzemplarzach: oryginał w archiwum, wpis w protokole sekretariatu stanu i kopia urzędowa, czyli wypis z protokołu sekretariatu stanu, powinien zawsze być zgodny co do treści. Według prawa odpowiadał za to minister sekretarz stanu. Niestety, przeglądając protokoły posiedzeń Rady Stanu, dowiadujemy się o uchybieniach w tym zakresie.

138 J. Willaume, dz. cyt., s. 81.

139 W. Rostocki, Kancelaria i dokumentacja, s. 104. 
Rada Stanu wielokrotnie zwracała się drogą urzędową do Brezy, aby przesłał poprawny wypis dekretu ze względu na błędy w pierwszym dostarczonym egzemplarzu ${ }^{140}$. W przypadku, gdy treść dekretu była niejasna, rząd zwracał się z prośbą o dokonanie sprostowania rozkazem królewskim ${ }^{141}$. Pomyłka, jak dowiadujemy się z odezwy Brezy, czytanej na posiedzeniu Rady, została także dostrzeżona

(...) $w$ dekrecie stanowiacym podwyższenie cta inwektowego od fabrykacji z lnu $i$ konopi i gdy NPan $w$ dekrecie względem cta omytkę dostrzeżona poprawić rozkazat i inny dekret $w$ tej mierze juź podpisać raczyt, przesyta nowy jego wypis, proszac o zwrot mylnie wydanego ${ }^{142}$.

Zdarzało się również, że sekretarz ekspedycji dopuścił się przeoczenia dokumentu podczas wysyłania poczty. W odezwie do Rady Stanu z lipca 1809 Breza przeprasza za uchybienie kancelarii, która przez pomyłkę nie załączyła w pierwszym liście kopii noty od saskiego ministra spraw zagranicznych ${ }^{143}$. W świetle powyższych informacji, trafną jest uwaga o dekretach, którą w biografii Fryderyka Augusta zamieścił Juliusz Willaume:

Atakowano przede wszystkim (...) dekrety królewskie, którym przypadato w udziale zazwyczaj ogtoszenie ze znacznym opóźnieniem, czyniacym nadchodzace do Warszawy zarządzenia czasem czystym anachronizmem (...). Co więcej, dekrety zawieraty niejednokrotnie rozporzadzenia tak przeciwne potrzebom chwili albo byty tak batamutnie przez Brezę wystylizowane, że czasem nie można byto dopatrzeć się ich wtaściwego sensu (... $)^{144}$.

Sprawne funkcjonowanie kancelarii rozpoznaje się po efektywności wykonywania poruczonych zadań. Istotną rolę odgrywa wiedza, znajomość zasad postępowania administracyjnego i dokładność naczelnika kancelarii, ale także każdego pracownika. Nie ma urzędów działających bez uchybień. Jednak jakość pracy rozpoznaje się także po sprawnej korekcie dostrzeżonych błędów. W Sekretariacie Stanu starano się nanosić poprawki, które sugerowa-

140 Protokoty Rady Stanu Księstwa Warszawskiego, t. 3, oprac. T. Mencel i M. Kallas, cz. 1, Warszawa 1995, s. 94.

141 Tamże, s. 97.

${ }_{142}$ Tamże, s. 117.

143 AGAD, RS i RM KW, seria II, sygn. 351, s. 29-31.

144 J. Willaume, dz. cyt., Poznań 1939, s. 109. 
ła Rada Stanu. Różnorodność spraw, załatwianych w jednej kancelarii, oraz skupienie kilku zadań u jednego pracownika czasami przerastała jego możliwości. Zwłaszcza że Breza w opinii współczesnych bardziej sprawiał wrażenie dworaka niż wybitnego administratora ${ }^{145}$.

Powróćmy jeszcze do wspomnianej Rady Stanu i protokołów z jej posiedzeń. W dekretach z dnia 24 grudnia 1807 roku oraz 19 września 1810, dotyczących organizacji rządu, Fryderyk August usankcjonował prawnie przewodniczenie posiedzeniom Rady ${ }^{146}$. Zdarzało się, że podczas pobytu w Warszawie król korzystał z przysługującego mu prawa i uczestniczył w sesji rządu warszawskiego. W tych wyjątkowych sytuacjach do zadań ministra sekretarza stanu należało także sporządzenie protokołu z sesji Rady Stanu oraz przekazanie go do wpisania do księgi protokołu ${ }^{147}$. Minister sekretarz stanu zobowiązany był także informować prezesa Rady Stanu o podróżach króla, w celu umożliwienia przepływu korespondencji urzędowej ${ }^{148}$.

Inną kategorię doraźnych kompetencji ministra sekretarza stanu z rozkazu króla stanowiło sporządzanie raportów czy projektów oraz paszportów. Przykładem jest paszport, umożliwiający przewiezienie kosztowności króla pruskiego przez Księstwo Warszawskie bez opłacania cła. Breza przygotował go na podstawie decyzji króla z dnia 13 czerwca 1812 roku $^{149}$.

\section{Bibliografia}

Chorążyczewski W., Nowożytny dokument królewski. Możliwości badawcze, [w:] Polska kancelaria królewska czasów nowożytnych między wtadza a spoteczeństwem, pod red. W. Chorążyczewskiego i W. Krawczuka, Toruń 2003.

Chorążyczewski W., Degen R., Kancelarie „wtadców” polskich XIX i XX wieku. Rekonesans badawczy, [w:] Bellicum Diplomaticum II Thorunense, pod red. W. Chorążyczewskiego i J. Tandeckiego, Toruń 2007.

Grygier T., H. O. Meisner, Urkunden Und Aktenlehre der Neuzeit, Leipzig 1952, „Archeion", t. 25, 1956.

Hahlweg W., Die Grundzuge der Verfassung des Sächsischen Geheimen Kabinetts 1763-1831, „Zeitschrift für die Gesamte Staatswissenschaft”, Bd 103, 1943.

145 Tamże, s. 79.

146 Dekret o organizacji Rady Stanu, s. 65-66. Por.: Dekret o organizacji ministerstw, s. 77-78.

${ }_{147}$ Protokoty Rady Stanu Księstwa Warszawskiego, Toruń 1960, s. 83.

${ }_{148}$ AGAD, RS i RM KW, seria II, sygn. 351, s. 17.

149 AGAD, SSKW, sygn. 20, s. 634-635. 
Historia ustroju i prawa w Polsce 1772/1795-1918. Wybór źródet, oprac. M. Kallas i M. Krzymkowski, Warszawa 2006.

Kallas M., Konstytucja Księstwa Warszawskiego. Jej powstanie, systematyka i gtówne instytucje w zwiąku z normami szczegótowymi i praktyka, Torun 1970.

Konarski K., Archiwum Akt Dawnych w Warszawie, [w:] Straty archiwów i bibliotek warszawskich w zakresie rękopiśmiennych źródet, t. 2, Warszawa 1956.

Krzymkowski M., Status prawny urzędników Księstwa Warszawskiego, Poznań 2004.

Meisner H. O., Aktenkunde, Berlin 1935.

Palkij H., Kancelaria królewska w systemie politycznym Rzeczypospolitej. Problem analizy źródet masowych, [w:] Polska kancelaria królewska czasów nowożytnych między wtadzq a spoteczeństwem, pod red. W. Chorążyczewskiego i W. Krawczuka, Toruń 2003.

Pamiętniki Feliksa hr. Eubieńskiego ministra sprawiedliwości, oprac. W. Chomentowski, Warszawa 1890.

Protokoty Rady Stanu Księstwa Warszawskiego, t. 1, oprac. B. Pawłowski, cz. 1, Toruń 1960.

Protokoty Rady Stanu Księstwa Warszawskiego, t. 2, oprac. B. Pawłowski i T. Mencel, cz. 2, Toruń 1968.

Protokoty Rady Stanu Księstwa Warszawskiego, t. 3, oprac. T. Mencel i M. Kallas, cz. 1, Warszawa 1995.

Rostocki W., Kancelaria i dokumentacja aktowa urzędów administracji w Księstwie Warszawskim i Królestwie Polskim (do 1867 r.), Warszawa 1964.

Rostocki W., Z badań porównawczych nad ustrojem administracyjnym Księstwa Warszawskiego i Francji, „Czasopismo Prawno-Historyczne”, t. 13, 1961.

Rymszyna M., Gabinet Stanistawa Augusta, Warszawa 1962.

Szawłowski R., Najwyższe Państwowe Organy Kontroli w Polsce w XIX wieku, Warszawa 1999.

Towarzystwo Królewskie Przyjaciót Nauk 1800-1832, Księga II: Czasy Księstwa Warszawskiego 1807-1815, oprac. A. Kraushar, t. 1, Warszawa 1902.

Volumina Legum: Prawa, konstytucje i przywileje Królestwa Polskiego, Wielkiego Księstwa Litewskiego i wszystkich prowincji należących, t. IX, Kraków 1889.

Willaume J., Fryderyk August jako książę warszawski, Poznań 1939.

\section{$S$ u m m a ry}

Secretariat of State of the Duchy of Warsaw (1807-1813)

The office of the Duchy of Warsaw Minister Secretary of State was created pursuant to the adoption of 1807 Basic Law. The Secretariat of State for the Duchy of Warsaw was an auxiliary apparatus for the minister State Secretary, with its main office located in Dresden, in consequence to the duties of the service. Thus, the office oper- 
ated between 1807 and 1813. The responsibilities of the minister determined all the most important duties of the Secretariat of State. The system by which the administrative office had functioned was subordinate to those responsibilities. The quality of work, given the overload of assignments, had, at times, left much to be desired. However, The State Secretary Office was the only way, the citizens were able to contact the monarchy. The so-called HRH Cabinet of Stanislaw August was similar to the Saxon Cabinet, and the Secretariat of State served as the chancellery of the Saxon king. Therefore, in the case of this particular Royal Chancery, we can expect the preexisting order to be upheld rather than introduction of the new filing system, which is characteristic for the 19th century.

The most important argument for applying the well-proven solutions in the Secretariat of State, was the fact, that the Saxon king was adverse to dramatic change.

In spite of the fact that the Duchy of Warsaw had been introduced to modern political regime and way of operating the chancery, the Kingdom of Saxony was more conservative at the time. Fryderyk August was very cautious about the Duchy being reformed and he didn't intend to introduce the same kind of changes to the Saxon state. This could also be the reason for his being skeptical about the modern approach to case filing. With regard to that, the solutions used to organise the secretariat of State were similar to the ones popular in the 18th century, modified, in order to cater to the needs of the affairs of the Duchy of Warsaw. Polish royal chancellery, which the Secretariat of State of the Duchy of Warsaw should be considered, was modernized by well-developed reference tools. General lodgement records were only just being brought on into Stanisław's chancellery.

Content of any copy of a given Royal Act, that is, the original document in the archives, as well as official copy - in other words - excerpt from the registry of the secretariat of state, should be consistent.

According to the law, this was the responsibility of the Minister Secretary of State. Alas, many shortcomings have been discovered in that regard, while browsing the Council of State memorandums. 